
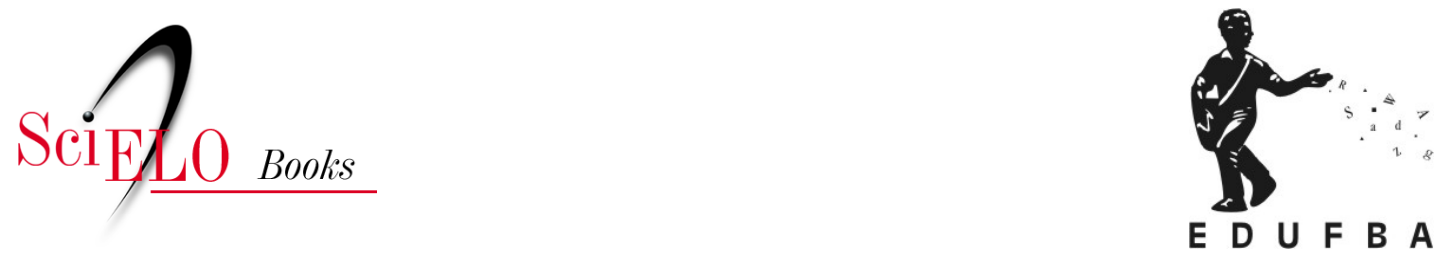

\title{
(Re)solidarizar as organizações
}

\author{
Genauto Carvalho de França Filho \\ Philippe Eynaud
}

\section{SciELO Books / SciELO Livros / SciELO Libros}

FRANÇA FILHO, G. C., and EYNAUD, P. (Re)solidarizar as organizações. In.: Solidariedade e organizações: pensar uma outra organização [online]. Salvador: EDUFBA; Ateliê de Humanidades, 2020, pp. 105-201. ISBN: 978-65-5630-199-0. https://doi.org/10.7476/9786556301990.0004.

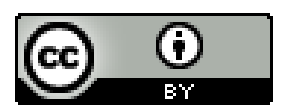

All the contents of this work, except where otherwise noted, is licensed under a Creative Commons Attribution 4.0 International license.

Todo o conteúdo deste trabalho, exceto quando houver ressalva, é publicado sob a licença Creative Commons Atribição 4.0.

Todo el contenido de esta obra, excepto donde se indique lo contrario, está bajo licencia de la licencia Creative Commons Reconocimento 4.0. 


\section{(Re)solidarizar as organizações}

Vimos no capítulo anterior que a organização de solidariedades é possível denunciando o sofisma dos economistas e adotando um quadro de referência estendido à economia substantiva. A partir de então, tornam-se visibilizadas no campo econômico lógicas essenciais para a solidariedade, como a reciprocidade, a redistribuição e o compartilhamento doméstico. Vimos também que essa mudança de quadro analítico abre uma interrogação em torno de uma racionalidade em valor e a necessidade de uma atenção à questão das mercadorias fictícias e sua reimbricação social. Com base nessas lições, podemos agora nos questionar sobre as condições requeridas para re-estabelecer a solidariedade nas organizações ou (re)solidarizar as organizações. Analisaremos para este propósito as diferentes formas de governança democrática que podem ativar tais processos no coração das organizações. Mostraremos então que essa (re)solidarização das organizações favorece a possibilidade de uma reconciliação entre o econômico e o social. Concluiremos este capítulo com exemplos de reconciliações decorrentes da reimbricação organizacional das mercadorias fictícias e da inovação social que dela resulta.

\section{PELA BUSCA DE UMA GOVERNANÇA DEMOCRÁTICA}

(Re)solidarizar as organizações não se decreta. A solidariedade não pode ser introduzida nas organizações simplesmente pelo uso de técnicas ou ferramentas de gerenciamento particulares - mesmo que elas não devam ser negligenciadas. A solidariedade não pode ser compreendida numa perspectiva funcionalista pois ela pressupõe uma intersubjetividade em atos. Como explica Tocqueville: "Os sentimentos e as ideias só se renovam, o coração só 
se amplia e o espírito humano só se desenvolve pela ação recíproca dos homens uns com os outros". (TOCQUEVILLE, I848, p. 219) A associação está no centro da reciprocidade evocada por Tocqueville e da solidariedade que ela exprime. Ela se situa em um nível intermediário entre as socialidades primárias e secundárias. (TÖNNIES, 20I0) Ela traduz esse vínculo possível entre os interesses de cada um e o espaço comum da cidadania. Por esse posicionamento particular, o fato associativo é indissociável da democracia. (LAVILLE, 20I8) Nesse sentido, a associação se constitui em um modelo para a organização solidária. De fato, se considerarmos a economia solidária como o projeto de democratização da economia (LAVILLE, SALMON, 20I6), a gestão solidária pode ser definida por analogia como o projeto de democratização da gestão. Portanto, a perspectiva pertinente para considerar o fortalecimento da solidariedade nas organizações é da ordem de uma governança democrática. (LAVILLE; YOUNG; EYNAUD, 2OI5)

\section{A governança das associações}

A iniciativa associativa se constrói num duplo movimento de internalização e de externalização. A associação internaliza as questões de sociedade e externaliza sua ação com o objetivo de transformação social. (BUCOLO; EYNAUD; HAERINGER, 20I5) Esse posicionamento particular induz "uma dinâmica associativa deliberadamente inscrita na ação pública" (BUCOLO; EYNAUD; HAERINGER, 20I5) e coloca as associações numa relação de cooperação e confronto com os poderes públicos e de fortalecimento da sua coerência institucional. Se definirmos a governança como o alinhamento da organização e gestão no projeto da associação (LAVILLE; HOARAU, 2008), a governança é, então, a condição dessa coerência institucional. Toda intervenção na ação pública supõe de fato um trabalho de atualização e intercâmbio sobre o projeto associativo e uma análise crítica da organização. Essa análise é muitas vezes difícil de conduzir, porque pode ser guiada por pressões de racionalização externas. Estas, pelo seu peso importante, podem enfraquecer uma legitimidade em campo que fora pacientemente construída no longo prazo. 
A pressão dos financiadores pode ser forte para incitar a adoção de "boas práticas", isto é, a padronização de práticas associativas. Existe, portanto, o risco de que a governança associativa se transforme gradativamente, através desse tipo de pressão, em um modelo próximo àquele das empresas. Não parece desnecessário lembrar que a governança corporativa (das empresas) é uma resposta à assimetria de informações entre os dirigentes e os acionistas, além de uma necessidade expressa pelos teóricos liberais de se restabelecer contra-poderes em proveito dos acionistas. De acordo com a economia ortodoxa, há de fato uma assimetria de informação entre o dirigente assalariado - presente no cotidiano da empresa - e o acionista - presente uma vez por ano na assembleia geral. O surgimento do conceito de governança se traduz, portanto, de acordo com Chandler, na transição da "empresa empreendedora" para a "empresa gerencial". (CHANDLER, I992) Por sua cultura das cifras, a "empresa gerencial" autoriza o controle de ações passadas. É interessante notar que a governança corporativa se traduz de fato por uma forma mínima de transparência. Doravante, podemos dizer com Perez que a governança nasce com "a gestão da gestão" (PEREZ, 2009), ou seja, com o controle do gestor por um outro gestor - trabalhando em nome dos acionistas -: o auditor. A governança se torna então um mercado em si mesmo para empresas especializadas em auditoria. Estas, fomentam a profissionalização gerencial - tornar as empresas então "empresas gerenciais" -, que é a condição da sua atividade, e sanciona aquele que é o produtor da gestão - isto é, o próprio gestor - quando ele escapa das chamadas "boas práticas".

Contudo, em tais condições, o que pode significar uma auditoria associativa? Como traduzir em números os elementos qualitativos relativos ao objeto social e a solidariedade? Como evitar que a governança comece a funcionar em favor do ator mais forte - na maioria das vezes, o financiador, no caso de uma associação - e não coloque em risco o projeto associativo? O que significa o conceito de "performance" aplicado a uma associação? Concordamos então com Naro para reafirmar que um trabalho de desconstrução de conceitos da gestão oriundos do mundo mercantil é fundamental. Este trabalho deve ser 
feito de forma situada, em cada um dos contextos específicos onde ele se dissemina. Ou seja, "dar outro sentido às palavras em gestão para curar os males da sociedade". (NARO, 2015, p. 175)

Entendemos que o desafio da governança associativa é evitar o risco de tal confinamento normativo. O perigo é exatamente o de uma redução do projeto associativo pelas pressões organizacionais provenientes do mercado. (EYNAUD, 20I5) Diante desses desafios, a busca pela governança democrática é uma forma de preservar a inventividade do coletivo e sua capacidade de ser um vetor de inovação social. Cabe à governança democrática explorar modelos alternativos baseados nas necessidades de uma economia substantiva. Uma reflexão sobre outras instâncias de governança que o conselho de administração, o escritório ou as comissões é então possível. Ela abre a possibilidade de novos modos de organização (LALOUX, 20I5), como a sociocracia e a holacracia. A sociocracia designa, de acordo com um termo de Comte, um modo auto-organizado, sem poder centralizado e com métodos distribuídos de tomada de decisão. (ENDENBURG, 1988) A holacracia, por sua vez, pode ser abordada como uma forma de sociocracia operando por círculos, num modo de organização fractal.

Neste contexto mais amplo do campo da economia substantiva, a governança democrática pode ser um vetor para a emancipação se resultar em:

- espaços de reflexividade coletiva e debate para poder julgar a coerência das escolhas organizacionais feitas em relação ao projeto associativo (LAVILLE, SAINSAULIEU, 2004);

- coconstrução de indicadores de monitoramento da atividade entre os diversos stakeholders, a fim de julgar coletivamente os resultados obtidos. Isso requer uma atitude crítica no que diz respeito à produção de dados e uma tomada de consciência que pode resultar na produção de indicadores substantivos, no sentido de Polanyi. Esse tipo de trabalho, iniciado em econômica num plano global, deve agora ser perseguido no nível das organizações, a fim de descortinar outra abordagem da riqueza (VIVERET, 2004); 
- espaços de convivialidade para aprender a debater, deliberar e gerir conflitos entre atores que não compartilham as mesmas referências ou os mesmos interesses. Assim, "a convivialidade, os laços de amizade, as relações que se podem manter com seus vizinhos e a partilha aparecem como riquezas importantes e valores centrais da vida. Mas, essas riquezas não são contabilizadas em nenhuma parte e, portanto, não contam ou contam pouco" (RENAULT, 2OII, p. I67);

- coprodução de novas regras e novas ferramentas para regular a ação coletiva. Sem esta invenção, o risco é efetivamente de ficar preso no arsenal de procedimentos e técnicas preexistentes e, ao fazê-lo, ficar preso num isomorfismo organizacional.

No entanto, esses critérios de emancipação são, eles próprios, condicionados por duas perspectivas de trabalho se abrindo sobre um conjunto de questões. A primeira perspectiva diz respeito às condições para a abertura do escopo dos atores envolvidos no projeto e as modalidades organizacionais dessa abertura para organizar a governança de múltiplas partes interessadas. Nesse sentido, quem são os atores relevantes para o projeto? Como pode-se associá-los? Como motivá-los? Como gerir o crescimento do número de atores envolvidos e sua heterogeneidade? Como produzir formas de coconstrução em ambientes pluralistas?

A segunda perspectiva diz respeito à difícil questão da fratura social e à proposição de uma governança inclusiva. Existem pré-requisitos para a governança? Deve-se partilhar competências mínimas para participar da governança? Se sim, quais são elas? Como formar os membros, mantendo a diversidade de visões e de pontos de vista? Deve-se, pelo contrário, adaptar as estruturas de governança para valorizar as competências dos atores? Como se certificar de que a questão da competência não é um pretexto para deixar de lado certos atores? Como integrar as pessoas distanciadas da ação pública? Como superar as aporias das práticas de participação? 


\section{A governança de múltiplas partes interessadas}

Garantir a pluralidade de um coletivo aparece como uma questão essencial para uma organização que deseja se inscrever na ação pública. (LAVILLE, SALMON, 20I5a) Arendt havia notado isso quando salientou que "a terra não é habitada por um homem, mas por homens". (ARENDT, 1994, p. 248) A pluralidade no campo político abre formas de ação coletiva particularmente interessantes pois ela remete a lógicas de ampliação e de abertura dos processos decisórios.

As organizações com múltiplas partes interessadas têm a particularidade de reunir em torno do mesmo projeto atores muito diferentes: assalariados, voluntários, beneficiários, usuários, financiadores, simpatizantes. De um ponto de vista neoinstitucional, essas organizações são capazes de minimizar os custos associados às assimetrias de informação. De fato, a colaboração do conjunto de atores envolvidos dentro das mesmas instancias de governança limita as áreas cinzentas e aumenta a capacidade de compreensão e resolução de problemas. A multiplicidade de olhares cruzados é uma contribuição inegável para a qualidade da gestão, pois permite compartilhar muitas informações, confiar no controle recíproco dos atores e inovar mais facilmente. (BORZAGA, DEPEDRI, 2009) Os atores podem incusive ser convocados para intervir em vários registros "como consumidores de serviços públicos (usuários cidadãos), como co-realizadores, como controladores, como trabalhadores". (BACQUÉ; REY; SINTOMER, 2005) Isso acentua seu envolvimento e favorece a pluralidade de olhares.

De um ponto de vista mais amplo, essas organizações são de grande interesse, pois têm boa propensão para atender às necessidades não satisfeitas e são capazes de coletar numerosos recursos, sejam eles mercantis, não mercantis ou não monetários. (BORZAGA; DEPREDI, 2OI5) Elas são capazes de produzir capital social (PUTNAM, 1993) potencialmente compartilhável com as pessoas mais marginalizadas em um objetivo de confiança. A evolução das formas organizacionais ao longo dos últimos anos demonstra o desejo de levar em conta a contribuição desse tipo de organização com múltiplas partes interessadas. 
A criação de Sociedades Cooperativas de Interesse Coletivo (SCIC) foi um exemplo na França. São estruturas legais projetadas para trabalhar com um colégio de atores não reduzidos aos funcionários e beneficiários. Elas incluem em seu funcionamento todos os cidadãos interessados na ação engajada.

No entanto, as organizações com múltiplas partes interessadas enfrentam vários desafios. A reunião de um grande número de atores com diferentes interesses em torno do mesmo projeto não é fácil de gerir. (VALÉAU; EYNAUD; CHATELAIN-PONROY; SPONEM, 20I8) A partilha de informações e a comunicação entre os membros é um processo complexo. Incompreensões podem ser fontes de tensão e ameaçar a coesão do coletivo. Além disso, a presença de usuários e beneficiários no processo de tomada de decisão pode induzir uma deriva tendendo ao consumismo. (CHAUVIÈRE; GODBOUT, I992) O compartilhamento democrático de decisões pressupõe um formalismo e procedimentos que podem parecer pesados - até contraproducentes - para certos atores.

O problema da vigilância em termos de solidariedade é o da "articulação dos diferentes círculos de solidariedade. Essa articulação é necessária para que as solidariedades locais não se degenerem em tantas formas de egoísmos categóricos e que, inversamente, o Estado não pretenda ditar sua concepção de solidariedades civis". (SUPIOT, 20I5, p. I7) Com efeito, a solidariedade implica sempre um "perímetro de apoio mútuo que inclui aqueles que une, mas exclui ou combate os outros". (SUPIOT, 2015, p. I4) Uma solidariedade de ação aberta pressupõe, portanto, como Supiot enfatiza, a expressão de solidariedades coletivas capazes de se combinar com uma visão evolutiva de justiça social. De fato, o princípio da solidariedade é, em parte, difícil de ser defendido porque tende a "fazer com que o interesse coletivo prevaleça sobre o interesse individual e o interesse dos membros do grupo sobre o dos estrangeiros para o grupo". (SUPIOT, 20I5, p. I5) É verdade que a solidariedade não é a mesma, dependendo do tamanho do grupo (ver Tonnies). A questão do tamanho joga com a capacidade de manter a coesão do grupo. A solidariedade pode fechar o grupo em si mesmo se a lógica do bode expiatório for permitida. (GIRARD, I972, I983) Por outro lado, a solidariedade pode abrir o grupo para o mundo 
exterior se for dada prioridade ao interesse geral. A escolha entre as duas opções pode estar condicionada por um eventual déficit de justiça social, induzindo a violência nas organizações. (HERREROS, 2012)

\section{A governança inclusiva}

A perspectiva de múltiplas partes interessadas que acabamos de mencionar não é necessariamente favorável às pessoas mais afastadas da ação pública. Estas podem se sentir desinteressadas pelas possíveis complexidades de seu funcionamento. A inclusividade supõe considerar a solidariedade como um meio de "igualar as condições". (SUPIOT, 2015, p. I3) Ela se distingue então da caridade na medida em que não divide o mundo entre "aqueles que dão sem receber e aqueles que recebem sem dar nada". (SUPIOT, 20I5, p. I2) Ao convidar todos os cidadãos a contribuir de acordo com seus meios e a receber de acordo com suas necessidades, a solidariedade se expressa em uma reciprocidade com vocação igualitária. O problema é então de poder "passar dessa solidariedade social de certa forma natural para uma solidariedade organizada e efetiva, sem para tanto perder o essencial do impulso inicial" (LABORDE, 2015, p. II2), a fim de manter a solidariedade democrática.

Doravante, a questão das competências é central e se aloja no coração da questão da inclusividade. Para participar da tomada de decisões, é necessário compartilhar conhecimento, trocar ideias com outros membros do coletivo, fazer escolhas. Tudo isso não é nada evidente quando se busca envolver atores socialmente marginalizados. A inclusividade deve, então, ser construída através de um trabalho paciente de capacitação, de acompanhamento e de mediação. É preciso se interrogar, conforme Zask nos convida, sobre a possibilidade de três momentos importantes: fazer parte, beneficiar e contribuir. (ZASK, 20II) A convivialidade é sem dúvida uma palavra-chave para habilitar esses diferentes momentos. O princípio básico do convivialismo consiste na "afirmação da comum humanidade e da comum socialidade de todos os seres humanos". (CAILLÉ et al., 20II, p. 2I) Mas, não é suficiente para responder à questão da competência e da expertise que o fundamenta. O debate entre 
Dewey e Lippman nos dá a chave do problema. (DEWEY, 20IO) Lippmann pensava que a presença e a mediação do especialista eram indispensáveis para tornar visíveis os problemas aos olhos dos cidadãos e dar-lhes os elementos de compreensão. Sem o especialista, o problema não pode ser apreendido e nem resolvido. Dewey pensa, ao contrário, que o especialista deve ser proscrito, enquanto portador de interesses privados categóricos que o impedem de servir plenamente o interesse público. Além disso, Dewey recusa a constatação de incompetência do cidadão. Ele propõe construir e expandir a experiência de cada um através de um dispositivo coletivo que ele chama de "investigação social". (DEWEY, 1967) Para Dewey, apenas uma abordagem de democracia radical é capaz de resolver os problemas das competências das pessoas socialmente marginalizadas. Esses métodos de investigação da animação coletiva podem ser jogados em espaços públicos de proximidade. (GARDIN; LAVILLE, 20I7) O grande desafio é de saber como organizar esses dispositivos. Isso pressupõe uma abordagem crítica e reflexiva sobre os dispositivos de gestão. Trata-se de revelar e prevenir seus efeitos potencialmente excludentes e favorecer aqueles que procedem de uma "democracia técnica", no sentido de Callon, Lascoumes e Barthe (200I), ou seja, de uma democracia dialógica na qual a técnica se coloca a serviço da resolução de oposições.

A questão da inclusividade impulsiona então a governança a se reformar e a melhorar sua capacidade de acolher e mobilizar os atores envolvidos no projeto. Isso significa, notadamente, analisar o grau de abertura das instâncias e ver como os atores beneficiários da ação podem ser implicados na organização dos serviços destinados a eles. Dois modelos de ação bottom-up estão disponíveis. (BACQUÉ; REY; SINTOMER, 2005) O primeiro é baseado em uma abordagem de empoderamento dos grupos populares e das minorias. Ele busca o consenso comunitário para assentar um poder decisório. O coletivo dispõe de uma forte autonomia para se atribuir regras cujo alcance é de escala microlocal. Nesse caso, não se busca incidir sobre o alargamento do perímetro dos atores, mas objetiva-se muito mais melhorar a inclusão dos membros já presentes. De certa forma, esse trabalho de inclusão é favorecido por um efetivo pequeno de pes- 
soas. O segundo elemento da democracia participativa é o compartilhamento da decisão com os responsáveis públicos locais. (BLONDIAUX, 2008) O procedimento implementado visa resolver o conflito pela organização de uma discussão coletiva em torno do interesse geral. As regras produzidas são codecididas e cogeridas com as autoridades locais. Há, nesse segundo modelo, uma forte dimensão política e ele se aproxima bastante de uma governança democrática.

\section{A governança democrática}

A governança democrática pode ser pensada no cruzamento das duas perspectivas que acabamos de evocar e descrever, para assim abrir um novo campo de pesquisa. (STEEN-JOHNSEN; EYNAUD; FILIP WIJKSTRÖM, 2OII) Numa abordagem de abertura, ela constrói um coletivo heterogêneo e cidadão para explorar o conjunto de dimensões de um projeto com os diferentes atores que o compõem e lhe dão sentido. Essa abertura inicia a inscrição numa abordagem de ação pública. Em uma perspectiva de inclusão, ela levanta a questão do acolhimento desses atores, do reconhecimento e da valorização de suas competências e as modalidades de sua participação nas decisões. A governança democrática entende, assim, ir além da solidariedade mais restrita, que garante a força de um coletivo local, para se inscrever num processo de solidariedade cidadã e ampliar o campo das competências admitidas para além das competências profissionais em uma abordagem convivial.

Quadro 1 - Tipologia dos modos de governança associativa

\begin{tabular}{|l|l|l|}
\hline $\begin{array}{l}\text { Competências, tipos de } \\
\text { governança e tipos de } \\
\text { solidariedade }\end{array}$ & $\begin{array}{l}\text { Solidariedade restrita dos } \\
\text { membros do coletivo }\end{array}$ & $\begin{array}{l}\text { Solidariedade cidadã inscrita } \\
\text { no espaço público }\end{array}$ \\
\hline $\begin{array}{l}\text { Competências focadas no } \\
\text { trabalho }\end{array}$ & Governança profissional & $\begin{array}{l}\text { Governança de múltiplas partes } \\
\text { interessadas }\end{array}$ \\
\hline $\begin{array}{l}\text { Competências abertas na } \\
\text { experiência dos atores }\end{array}$ & Governança inclusiva & Governança democrática \\
\hline
\end{tabular}

Fonte: adaptado de Eynaud e França Filho (2019). 
Na encruzilhada de caminhos, trata-se de fortalecer simultaneamente a "democracia representativa ao desenvolver a democracia participativa (aprofundando-a) e de democratizar a esfera econômica (ampliando-a)". (DACHEUX, GOUJON, 20I6, p. 204) No contexto dessas diferentes formas de governança, podemos explorar diferentes maneiras de prestar contas ou de se colocar em um processo de responsabilização - accountability. Esse termo tem dois significados: designa tanto o ato de prestar contas quanto a responsabilidade que está vinculada a ela. Isso significa que as associações devem prestar contas a seus financiadores e que essa prestação de contas as compromete. Assim, comunicar-se com um doador particular sobre a porcentagem de sua doação retornando para o beneficiário é tanto uma informação útil em si quanto um compromisso público. De fato, se essa porcentagem diminuir, a associação será levada a explicar e a motivar a evolução. Assim, Ostrower e Stone (2015) distinguiram três formas de accountability - ascendente, externa e interna - que podem ser ligadas ao quadro anterior. A forma ascendente corresponde às necessidades da governança profissional. As contas são construídas e apresentadas às autoridades públicas e aos financiadores que as solicitam. Essas contas são técnicas e não tem por vocação de serem discutidas com membros da associação. A forma interna corresponde aos relatórios para funcionários e voluntários e remete sobretudo à governança inclusiva. Trata-se de associar mais estreitamente a governança dos atores assalariados em inserção pelo trabalho com a gestão do coletivo. A forma externa é uma prestação de contas para beneficiários, usuários, redes, associações profissionais ou organismos de acreditação. O número de atores é grande e os perfis são muito variados. Essa forma externa é semelhante a governança de múltiplas partes interessadas pelo número de atores envolvidos. Os pesquisadores americanos não identificaram uma quarta forma, mas pode-se deduzir dessa análise que a governança democrática combina todas as formas de prestação de contas a fim de cruzá-las e colocá-las em perspectiva. Na governança democrática, a transparência prevalece e os dados são compartilhados entre todos os membros. 


\section{RE-SOLIDARIZAR AS ORGANIZAÇÕES ATRAVÉS DAS REDES NO TERRITÓRIO}

Se a governança democrática pode ser vista como um modo de re-solidarizar as iniciativas ou organizações locais, esta prática pode ser reforçada através da implantação de redes solidárias entre os atores no contexto de suas ações no território. As práticas solidárias no seio das organizações podem então se enriquecer e se desenvolver através do cruzamento com aquelas oriundas de outras organizações solidárias. Dito de outro modo, a solidariedade intraorganizacional se duplica de uma solidariedade interorganizacional. Num contexto de mercadorização crescente e de aumento da concorrência entre os atores dos territórios, as alianças e os reagrupamentos entre os atores e as organizações solidárias podem constituir um meio de resposta aos desafios multidimensionais da solidariedade, abrindo uma via de desenvolvimento territorial como vetor de uma outra economia.

\section{As alianças e os reagrupamentos}

Na França, as organizações de Economia Social e Solidária (ESS) conheceram mudanças importantes no seu meio ambiente institucional ao longo das últimas décadas. Uma das mais importantes foi o aumento das demandas governamentais, através dos editais públicos forçando a competição por projetos, cujo efeito forte foi de gerar concorrência entre as organizações de ESS. Essa mudança implicou o desenvolvimento de novas competências para os atores como a montagem de projetos, o acompanhamento analítico-consultivo e a gestão de indicadores, enquanto forma de se adequar as demandas de avaliação requeridas pelos financiadores. O tamanho e a tecnicidade dos projetos propostos favoreceram atores dispondo de uma estrutura maior e com elevada probabilidade de resposta. Desse modo, um amplo movimento de reestruturação foi empreendido, induzindo muitas fusões entre tais organizações. (EYNAUD; GÉROME, 20I4) Essa dinâmica teve o efeito de permitir as organizações de ESS de responder aos novos desafios, especialmente, à concorrência recente das empresas privadas se imiscuindo 
no campo social graças aos benefícios que tiveram com as mudanças institucionais. O aumento do tamanho dos atores pressupunha da parte deles uma mudança no seu modo de gestão. Esse fora profissionalizado e se aproximou dos métodos utilizados pelas organizações de mercado. A profissionalização, outrora sinônimo de competência no campo da ação, evoluiu na sua significação para designar cada vez mais a aquisição de uma competência gestionária. Como num jogo de dominós, os atores de menor porte e mais frágeis financeiramente foram levados a serem absorvidos pelas estruturas maiores a fim de perenizar seus empregos. Isso não ficou sem consequência em relação aos métodos de gestão dessas organizações, como também em relação aos seus projetos, sua imagem e a própria legitimidade de tais organizações. (MARIVAL et al., 20I5) Uma reestruturação pode também suscitar um questionamento do contrato psicológico que vincula as partes interessadas e provocar um sentimento de injustiça. (EYNAUD, SCHIMIDT, 20I2) Ela pode, enfim, anular a capacidade de identificação de novas necessidades e de inovação. É mister reconhecer que um dos males mais recorrentes em matéria de organização face a um problema é de buscar "resolvê-lo pelo alto através de uma organização de escala superior". (REY, 2OI4, p. 207) Na luta contra este tipo de deriva, muitos atores tentaram preservar seus respectivos projetos e se proteger da ameaça das fusões recorrendo à cooperação e à mutualização dos seus recursos e dos seus meios entre si. (EYNAUD; GUIBERT, 2OI2)

A mutualização pode assumir diferentes formas: partilha de um imóvel, de meios materiais, de competências, de práticas, de savoir-faire, de informações etc. Ela pode ser ou não estruturada juridicamente. Numerosas partilhas se realizam de maneira informal no quadro de relações de reciprocidade. Outros se organizam de modo mais estruturado. Um exemplo relevante na França a esse respeito são os chamados Pólos Territoriais de Cooperação Econômica (PTCE), reconhecidos pela lei francesa da economia social e solidária de 3I de julho de 20I4, no seu artigo 9: "Os polos territoriais de cooperação econômica são constituídos pelo agrupamento no mesmo território de empresas 
da economia social e solidária, na acepção do art. I dessa lei, que se associam às empresas vinculadas com as municipalidades e suas aglomerações territoriais, centros de pesquisa, estabelecimentos de ensino superior e de pesquisa, organismos de formação ou qualquer outra pessoa física ou moral, para implementar uma estratégia comum e contínua de mutualização, de cooperação e de parceria ao serviço de projetos econômicos e sociais inovadores, socialmente ou tecnologicamente, e trazendo desenvolvimento local sustentável"."

Na carta de princípios da rede do PTCE, algumas perspectivas são apresentadas: "Criar, consolidar e desenvolver atividades, de empregos duráveis e de qualidade em benefício do seu território e dos seus habitantes; trabalhar no enraizamento territorial de atividades econômicas, num espaço caracterizado pela cooperação entre partes interessadas; adotar uma governança democrática apoiando-se em princípios de equidade, de reciprocidade, sobre o engajamento voluntário das pessoas e associando o conjunto das partes interessadas; implicar no seu território cidadão ator e instituições de qualquer tamanho; investir na inovação social e na pesquisa de utilidade social, em resposta às necessidades sociais ou societais. Os valores comuns são os seguintes: ele respeita, mobiliza e valoriza seu patrimônio local, os recursos do seu território (humanos, naturais, materiais, culturais e financeiros) e se apoia sobre engajamentos dos seus atores (atrizes); ele se apoia sobre o respeito mútuo, a diversidade reconhecida, a confiança e a convivialidade, valor em ato do viver juntos e do fazer juntos; ele reconhece a co-construção, a formação e o conhecimento como eixos do desenvolvimento; ele pratica a solidariedade em ato no nível local e global; ele coloca à serviço do seu desenvolvimento a pesquisa de inovação social; ele promove e faz prova de criatividade à todos os estágios de sua evolução e da implantação de suas atividades; ele busca a qualidade das trocas na comunicação e na transmissão de informações". ${ }^{2}$

Por trás dessas alianças, reagrupamentos e suas modalidades, se desenha uma outra visão, uma outra compreensão do mundo. Contra a lógica dos

1 Disponível em: http://www.lelabo-ess.org/-poles-territoriaux-de-cooperation-economique.

2

Charte du Réseau des PTCE. 
grandes empreiteiros, essa visão vislumbra a relação com o outro como primordial e defende para as organizações solidárias um tamanho compatível com seus projetos. Contra a ideia difundida que tende a associar "o tamanho pequeno ao primitivo", essa visão demonstra por suas inovações que "o mais alto grau de civilização se acomoda à tamanhos modestos". (REY, 20I4, p. 87) Como demonstrou Guerreiro Ramos (1989) através da noção de paraeconomia trata-se de preservar as lógicas frágeis fundadas nos vínculos sociais, tal como se exprimem nas isonomias e fenonomias. Então, não se trata de fazer apologia do pequeno e sim de buscar em tudo "o tamanho mais apropriado à auto-realização e a fecundidade das existências". (REY, 2OI4, p. IO2)

No Brasil, um exemplo valioso são experiências muito pouco conhecidas de criação de redes locais de economia solidária em áreas consideradas de alto grau de vulnerabiliadde socioeconômica, como bairros populares na periferia de centros urbanos, comunidades rurais e/ou comunidades tradicionais próximas ou distantes de áreas populacionais maiores. Tais experiências surgem a partir de dinâmicas sociopolíticas locais de auto-organização como associações de moradores que se articulam com outras iniciativas locais de natureza socioeconômica ou sociocultural e socioambiental para o desenvolvimento de atividades conforme as necessidades e demandas do território. Tais redes têm o intuito de repensar a reorganização das economias locais em conexão com as demandas do lugar. As iniciativas criadas têm caráter tanto socioprodutivo quanto socio-organizativo. A formação de tais redes envolve as formas preestabelecidas de organização econômica e demais instituições do próprio território. Razão pela qual o processo de mobilização dos atores requer diferentes práticas de inovação social, na relação com o comércio local, por exemplo, ou com a prefeitura, ou ainda, com atores institucionais variados para além do território - organizações da sociedade civil, instituições públicas e/ou privadas, incubadoras tecnológicas de economia solidária vinculadas às universidades e centros de pesquisa, entre outros.

Dentre as inovações locais observadas tem sido relevante o papel desempenhado pelos bancos comunitários de desenvolvimento e a circula- 
ção de moedas sociais na dinâmica de constituição de tais redes. (FRANÇA FILHO, CUNHA, 2OIO; FRANÇA FILHO, 2OI3; RIGO; FRANÇA FILHO, 2OI7) Como exemplos de casos, é importante mencionar a rede constituída em torno da experiência do banco palmas no bairro do conjunto palmeiras na periferia de Fortaleza ou a rede constituída em torno do Banco Comunitário dos Cocais no município de São João do Arraial, no interior do Piauí.

\section{Pensar a economia de outra forma para conceber uma gestão solidária do desenvolvimento territorial}

Vimos assim como a governança democrática se elabora numa dialética em tensão entre suas dimensões interna e externa. Com efeito, ela pressupõe um duplo registro da ação sociopolítica. Trata-se, de um lado, de impulsionar e de manter localmente uma dinâmica cotidiana de auto-organização e, de outro lado, de se inscrever numa ação pública à vocação mais ampliada. É justamente essa dupla perspectiva que reforça a prática da democracia. Ela faz do território o lugar fundamental para o seu exercício. O território aparece assim como espaço de mediação ideal para vincular e traduzir as duas perspectivas. Nesse sentido, o processo de organização da solidariedade ligado à afirmação de uma outra economia torna-se um exercício de desenvolvimento territorial. Dito de outro modo, uma outra economia - como no exemplo de práticas de economia social e solidária - não pode se conceber independentemente da ideia de territorialidade. Isso nos conduz à uma dupla constatação: a) no plano analítico, o território e seu desenvolvimento é um elemento indissociável da compreensão de uma outra economia; b) uma outra economia é um elemento estratégico para a formulação de uma agenda renovada em matéria de desenvolvimento territorial. (FRANÇA FILHO, 20I9a)

Os dois tópicos citados anteriormente guardam uma relação direta e, por razões pedagógicas, podem ser abordados através de duas indagações absolutamente imbricadas. A primeira interrogação, de caráter eminentemente aplicado, suscita o tratamento de uma segunda indagação, de caráter mais conceitual: I) como desenhar uma estratégia de desenvolvimento territorial com 
base num olhar de outra economia? 2) como redefinir o papel e significado do econômico numa agenda renovada de ação para o desenvolvimento territorial? Se a ideia de outra economia constitui a resposta aplicada ao problema teórico mencionado na segunda questão acima, o intuito neste momento é de avançar na primeira questão sem, entretanto, deixar de reconhecer o caráter quase que indissociável das duas questões refletidas na dupla constatação observada no parágrafo anterior.

Numa abordagem econômica convencional, as duas questões acima não revelam pertinência. De fato, o território não tem verdadeiro interesse em si mesmo. Ele é apenas abordado e considerado na sua relação com a economia. Espera-se que o território esteja a serviço da empresa, mas esta última não está ligada ao território. Segundo os princípios econômicos do mercado autorregulado, a empresa fica livre para se deslocar em função dos seus interesses estratégicos e financeiros. Nessa ótica, a dinâmica territorial é guiada pela atividade econômica, sem que haja uma verdadeira contrapartida em direção ao território. Em outros termos, o território é visto como um vetor de atratividade e uma variável de ajuste suscetível de atrair os investidores ditos "produtivos". Em geral, o desenvolvimento das forças produtivas do mercado orienta a lógica do desenvolvimento territorial. Há, nesse caso, prevalência de princípios exógenos sobre os princípios endógenos. Ao enfatizar a atratividade do território, os capitais e os investimentos estrangeiros tornam-se os principais motores do desenvolvimento territorial. Três efeitos combinados aparecem como consequências correntes do desenvolvimento da lógica mercantil sobre os territórios: a) acentuação das desigualdades em médio e longo prazo, diante do efeito concentrador do investimento, mesmo que possa haver algum grau de efeito redistributivo econômico na cadeia produtiva no curto prazo; b) dependência das economias locais ou territoriais em relação à atividade produtiva objeto desse investimento; c) riscos de desinvestimento ou de desinstalação (deslocalização) que costuma ocorrer após um período médio da alta de ganho seguido de oscilações e diminuições desses mesmos ganhos em outros períodos. Se o desinvestimento é fruto da liberdade que 
usufruem as empresas, seu efeito costuma ser seguido de impactos dramáticos no plano sociocultural e ambiental. Essas constatações revelam a incapacidade dos meios convencionais de responder, a longo prazo, às necessidades de desenvolvimento territorial. Em tal contexto, é imperativo procurar alternativas. (FRANÇA FILHO, 2OI9a)

Se a busca de alternativas se inclina em favor de uma inflexão da relação entre economia e território, na perspectiva de um reenraizamento da economia no território, é porque as questões relativas ao desenho de novas estratégias de desenvolvimento territorial apenas conseguem ser formuladas e avançam num diálogo permanente com essa ideia de ressignificação do econômico. Uma forma de vislumbrar essa inflexão em termos conceituais e estratégicos corresponde à passagem de uma concepção insercional-competitiva do desenvolvimento para uma concepção sustentável-solidária. ${ }^{3}$ (FRANÇA FILHO, 2008) De todo modo, há uma falta geral de reflexão crítica sobre a natureza da economia em relação ao desenvolvimento territorial. Duas razões podem ser apresentadas para explicar essa ausência:

I. o pensamento de inspiração marxista, enquanto alternativa mais conhecida, oferece de fato uma crítica importante à racionalidade econômica de mercado, mas não vislumbra qualquer alternativa específica para o nível dos territórios. Seu esquema de análise permanece global e dependente da economia de mercado tornada necessária para operar a redistribuição estatal;

2. os estudos de antropologia econômica são ainda insuficientemente conhecidos e mobilizados em estudos sobre o desenvolvimento territorial. Sem eles, é difícil chegar ao coração da reflexão sobre a natureza profunda da economia.

3 A concepção sustentável-solidária repensa a ideia de geração de trabalho e renda na sua relação com o desenvolvimento local. 0 intuito é de requalificar o entendimento do empreendedorismo no sentido de uma maior valorização de iniciativas coletivas baseadas em mecanismos de cooperação e solidariedade levadas a cabo em redes e segundo as caraterísticas socioculturais, econômicas e ambientais do seu próprio território. O intuito é de escapar das soluções puramente exógenas e que ainda estimulam uma visão eminentemente individualista da ação empreendedora, conforme a concepção insercional-competitiva. (FRANÇA FILHO, 2008) 


\section{Como redefinir o papel e significado da economia na gestão territorial?}

Vimos anteriormente como é possível redefinir o sentido da economia, seja através dos estudos da antropologia econômica, seja através de uma outra concepção da teoria organizacional com Guerreiro Ramos (I989). Essa redefinição é um exercício de mudança do olhar. Trata-se, para os estudos do desenvolvimento territorial, de inverter a perspectiva convencional que consiste em compreender como o território é dependente da economia, para pensar uma redefinição da articulação entre economia e território. Isso nos convida a mudar de registro: ao invés de olhar a economia como um fim em si mesmo, buscar enxergá-la como meio para realização de outros propósitos.

Nesse sentido, a antropologia econômica desenvolvida por Polanyi (2012) é particularmente relevante. Esse autor distingue a definição formalista do econômico da sua definição substantiva. A economia formal estabelece uma conexão lógica entre meios e fins e postula como pré-requisito o princípio da escassez. Assim, ela pode ser pensada através do comportamento de maximização por parte de atores guiados por uma escolha racional. Em contraste, a economia substantiva escapa à visão abstrata da lógica de mercado. Ela se interroga de forma pragmática sobre a profunda dependência entre o ser humano e a natureza, bem como, entre os próprios seres humanos ao longo da história do desenvolvimento das culturas e sociedades humanas. Ele estuda a economia de subsistência e os meios necessários para cobrir as necessidades naturais. Para isso, Polanyi faz um desvio pela história econômica. Ao longo do tempo, ele mostra a pluralidade de formas de atividades econômicas, a diversidade de modos de regulação e sua evolução. Ele destaca através da sua análise dos princípios econômicos aqueles que o mercado tende a invisibilizar - como a redistribuição, a reciprocidade e compartilhamento doméstico.

A força da abordagem de economia substantiva reside em sua ênfase na questão da reprodução social. Enquanto a economia de mercado permanece focalizada na produção econômica, o olhar antropológico amplia nossa visão de mundo. Ele nos permite refletir sobre os meios pelos quais as sociedades 
constroem suas condições materiais de existência e de vida social. Segundo Weber, a ação econômica pode ser considerada como um tipo de ação social. Desse modo, a análise econômica não pode subtrair a questão da reprodução da vida social. Aqui, a abordagem não é abstrata, ela se constrói historicamente na sua relação com um dado território. Trata-se, na prática, de compreender como a economia constrói localmente suas relações com as esferas social, cultural, política e ambiental. Alguns ensinamentos podem, assim, serem discernidos. Em primeiro lugar, a compreensão ampliada da economia tornada possível com a antropologia econômica abre o caminho para a exploração de uma outra economia. Em seguida, a visão da economia é transformada pela sua inscrição nas esferas da vida em sociedade. Além disso, a dimensão institucional e o caráter situado do território orientam os estudos sobre o desenvolvimento territorial na direção de uma abordagem solidária. Enfim, a outra economia desenhada pelo olhar antropológico compreende uma diversidade de formas de economia em interação, conforme veremos a seguir com o conceito de economia plural.

\section{Gestão territorial e economia plural}

A visão de economia plural representa um esforço de ampliação da compreensão do que é o econômico levando-se em conta o legado de conhecimento oriundo da antropologia econômica. Com essa visão, a economia deixa de ser vista apenas como econômica de mercado para incluir mais três outros princípios ou formas de economia: a redistribuição, a reciprocidade e o compartilhamento doméstico. A noção de economia plural contém nela mesma duas ideias, quais sejam: I) ela é intrinsicamente adaptada à possibilidade de uma transição social e ecológica, em razão do pluralismo que ela pressupõe; 2) ela tem o objetivo de garantir o equilíbrio entre os diferentes componentes ou lógicas que a formam. O caráter hegemônico da dimensão mercantil deve ser contido a fim de deixar espaço aos outros componentes, conforme a dupla acepção do verbo conter. Se a economia plural pode conter a lógica de mercado, é preciso então definir precisamente esse conteúdo, 
isto é, um perímetro em que o mercado seja possível. É preciso, em seguida, refletir sobre os meios de prevenir uma possível extensão predatória, afim de conter possíveis externalidades negativas. As duas acepções do verbo conter, nesse caso, indicam um horizonte de regulação socioeconômica enquanto estratégia de governança democrática, dirigida para três aspectos articulados. Em primeiro lugar, trata-se de domar os efeitos destrutivo da racionalidade de mercado, contendo-a. Em segundo lugar, trata-se de favorecer o potencial do próprio princípio do mercado, quando suas práticas são ressignificadas, isto é, são modificadas através da introdução de mecanismos de auto-organização, fundado em valores de cooperação e solidariedade, redefinindo as regras das relações de comercialização, produção, consumo e financiamento. Em terceiro lugar, trata-se de fomentar o potencial contido nas diferentes formas ou princípios econômicos radicalmente distintos do mecanismo de mercado. É neste sentido que a governança democrática pode desempenhar seu papel de regular a atividade econômica, promover a cooperação e favorecer lógicas econômicas para além do mercado. O enriquecimento da democracia no território é a condição desta regulação.

Uma estratégia de desenvolvimento territorial renovada - pois inspirada nas noções de economia plural e de paraeconomia - supõe uma agenda que a inscreva no quadro de uma política pública. Para tanto, uma reflexão sobre a regulação deve ser engajada com as instituições. Trata-se, em primeiro lugar, de reanalisar a relação de mediação ou de negociação com os atores externos e os investidores. Os possíveis aportes externos devem ser filtrados segundo critérios permitindo favorecer o conjunto da sociedade local. A regulação é, então, vista como um sistema de proteção em condições de impedir as externalidades negativas dos investimentos que chegam. Trata-se, igualmente, de abrir um tempo para a reconstrução institucional, isto é, para a dimensão endógena da análise, da concepção e da ação territorial. Esses dois tempos de concepção e ação permitem lançar, a título propositivo, um esboço de política pública de desenvolvimento territorial fundado numa ressignificação do econômico, ou seja, fundado na própria ideia de economia plural. 


\section{Desenhando uma proposta: esboço de uma política de gestão solidária de territórios}

As grandes linhas de uma tal política se desenham segundo dois níveis estratégicos e quatro eixos de intervenção. Os dois níveis são, então, denominados de regulação institucional e de reconstrução institucional. A reconstrução institucional não deixa de ser uma regulação institucional, na medida em que ela implica um modo específico de operar, fundado num arcabouço institucional, bem como, um modo de provisão de bens e serviços. De todo modo, por regulação institucional, entende-se a relação de mediação ou negociação com a economia preestabelecida e os potenciais agentes externos enquanto investidores. Essa visão da política pública não pretende fundá-la simplesmente na atração de investimentos privados externos, mas quer pensar sobre como esse investimento externo pode efetivamente favorecer o conjunto da sociedade local. Regulação, aqui entendida como mediação, é um modo de avaliar e corrigir possíveis efeitos de externalidade negativa do investimento e salientar o potencial de efeitos externalizadores positivos para o território. Como um determinado grande empreendimento privado pode oferecer contrapartidas à sociedade local em temos de reinvestimento? Quais as diferentes formas de investimento externo que não estão baseadas numa lógica de mercado convencional? Essas questões indicam alguns caminhos em termos de regulação institucional. Em complemento, por reconstrução institucional, entende-se todos aqueles investimentos inovadores do ponto de vista do desenvolvimento das atividades - novos tipos de agentes ou atores socioeconômicos, novos tipos de arranjos ou redes inter-atores etc. Enquanto a reconstrução institucional enfatiza o endógeno - ou a relação endógeno-exógeno -, a regulação institucional lida fundamentalmente com o exógeno.

No que diz respeito aos eixos de intervenção, os três primeiros representam princípios de ação pública em matéria de reconstrução institucional: o princípio mercantil ressignificado; o princípio redistributivo; e o princípio reciprocitário. O quarto eixo diz respeito à relação com os investidores externos e exprime uma modalidade de regulação institucional. Os quatro eixos 
de intervenção não devem ser concebidos como práticas isoladas. Suas distinções revelam de maneira analítica a natureza específica de cada princípio econômico, mas suas complementaridades devem ser sublinhadas e valorizadas na prática. A tradução do conceito de economia plural permite não apenas modelizar as formas específicas de ação econômica como também inventar formas de ação combinando - ou fusionando - a diversidade dos princípios econômicos. A implantação desses eixos não obedece a uma ordem particular a priori, nem a uma hierarquia qualquer. A maior ou menor importância acordada a cada um dos eixos é definida pela demanda e características do contexto local.

Quadro 2 - Eixos e níveis estratégicos na gestão territorial solidária

\begin{tabular}{|l|l|}
\hline Níveis Estratégicos & Eixos de Intervenção \\
\hline Eixo de reconstrução institucional & 1 - Mecado ressignificado \\
\cline { 2 - 2 } & 2 - Redistribuição \\
\cline { 2 - 2 } & 3 - Reciprocidade \\
\hline Eixo de regulação institucional & 4 - Busca de investidores solidários \\
\hline
\end{tabular}

Fonte: França Filho (2019a).

O primeiro eixo consiste em revalorizar o princípio mercantil no sentido de uma ressignificação de suas práticas. Para tanto, trata-se de introduzir mecanismos de cooperação e de solidariedade entre os agentes econômicos nas atividades locais de produção, de prestação de serviços, de comercialização, de consumo e de serviços financeiros. Esse eixo enfatiza a necessidade de um suporte à criação e/ou consolidação de organizações de economia solidária. Ele conduz as políticas públicas a sustentar, nas suas ações, as cooperativas, as associações, as fundações e Empreendimentos Econômicos Solidários (EES). A vocação de tais políticas deve ser ampla e incluir as iniciativas privadas com fins lucrativos que adotam ou empreendem modelos de negócios capazes de compartilhar ou de produzir efetiva distribuição de riqueza. 
O objetivo do eixo é de apoiar os atores que inovam, operando um trabalho de ressignificação das atividades de mercado. Os exemplos são numerosos e particularmente promissores, tanto no contexto nacional quanto na realidade internacional. Podemos salientar o caso do comércio justo e solidário, uma das primeiras práticas inovadoras nesse sentido. As organizações do comércio justo se colocam, com efeito, no espaço do mercado para modificar suas regras por dentro. Com os seus produtos, eles quebram o livre jogo do mercado para inventar um novo enquadramento na origem das trocas mercantis, segundo regras sociais e ecológicas. Assim, o comércio justo trabalha com os pequenos produtores nos quais ele garante um preço fixo, no qual estes poderão planejar razoavelmente suas economias domésticas. O preço de compra é, desse modo, subtraído, via regras autoproduzidas, dos mecanismos de livre fixação dos mercados. Um outro exemplo pode ser encontrado no âmbito dos chamados circuitos curtos, na França, especialmente através das Associações de Manutenção da Agricultura Camponesa (AMAP) - association pour le mantien de l'agriculture paysanne.

Essas associações criam um vínculo entre as áreas de exploração agrícola familiar com os coletivos de consumidores de suas vizinhanças. Trata-se de um acordo ou entendimento sobre a venda da produção em condições justas para o produtor. Este pode melhor planificar sua atividade e escapar dos ditames impostos pelos intermediários. Autoriza-se, nesse caso, trocas de serviços gratuitos entre consumidores e produtores. Essa experiência tem se difundido mais recentemente em diferentes países, inclusive o Brasil, através dos Consumidores Sustentam Agricultura (CSA). De fato, no Brasil, experiências similares e menos recentes têm sido empreendidas, através dos chamados grupos de consumidores responsáveis e outras práticas de cooperativismo de consumo. De qualquer sorte, o conjunto de tais iniciativas se situam entre inúmeras outras experiências que na realidade brasileira participam do universo mais amplo das práticas de economia solidária, como as finanças solidárias através das cooperativas de crédito solidário, dos bancos comunitários de desenvolvimento e o uso de moedas sociais, dos fundos rotativos solidários, além de uma 
enorme diversidade de outras experiências indicando outras temáticas: turismo de base comunitária, empresas recuperadas, cooperativismo de plataforma etc. Nesse contexto, experiências de redes locais de economia solidária, conforme aludidas anteriormente, indicam importante potencial de contribuição. (FRANÇA FILHO, 20I3; RIGO; FRANÇA FILHO, 2OI7; RÊGO, 2OI4)

O segundo eixo de ação diz respeito ao melhor uso do potencial transformador do princípio redistributivo, pela sua capacidade em gerar uma lógica de economia não mercantil. As políticas públicas se encarregam, neste nível, de financiar atividades portadoras de forte potencial de transferência e de realocação de recursos, além de elevado impacto social. Trata-se de atividades que nem sempre podem gerar todos os recursos de que necessitam através do seu próprio autofinanciamento, mas que possuem forte potencial de socialização, além de outros indicadores de utilidade social. Elas contribuem com o fortalecimento dos vínculos sociais ou com a elevação do nível de conhecimento e formação das pessoas que se encontram afastadas da ação pública, ou ainda, com o necessário trabalho de reconhecimento e de identidade dos grupos e indivíduos marginalizados. O esforço da política pública se situa, então, no ponto cego das atividades de mercado e das análises clássicas do desenvolvimento territorial. Esse tipo de suporte público participa de uma estratégia de longo prazo de revalorização do território até suas áreas remotas e o apoio à população, incluindo aquela de muito maior dificuldade de acesso. A proposta desse eixo é a de financiar atividades não geradoras de recursos próprios, mas com alto potencial de bem-estar social nos campos do esporte e da arte e cultura em geral, através de um criativo programa de bolsas auxílio. O caso de uso de um sistema público de remuneração através do dispositivo das moedas sociais eletrônicas e em articulação com a rede brasileira de bancos comunitários de desenvolvimento levado a frente pela prefeitura de Maricá, no Rio de Janeiro, constitui experiência inspiradora.

Os benefícios de uma reorientação dos fluxos da riqueza no território com base neste segundo princípio pode ser melhor refletida à luz das contribuições mais recentes trazidas por pesquisadores da Universidade de Grenoble 
através da sua proposição de uma "teoria da base econômica". (TALANDIER, 20I6) Nesse sentido, parece relevante a noção de "economia residencial" em Davezies (2008). Esse conceito indica o conjunto dos fluxos de renda captados pelos territórios independentemente da sua capacidade produtiva. Esse autor chama a atenção para a importância de uma infinidade de outros "fluxos de riquezas" (DAVEZIES 2004), a exemplo de despesas de turistas, montante das aposentadorias ou salários de imigrantes, entre outros, que não estão ligados à produção e que podem constituir motores do desenvolvimento. Em outros trabalhos (TALANDIER et DAVEZIES, 2009), os autores salientaram a desconexão crescente entre desafios do crescimento, da produção, da exportação e os desafios do desenvolvimento, no sentido da melhoria qualitativa das condições de vida das populações. De fato, os territórios onde se produzem mais riquezas não são necessariamente os territórios que mais se aproveitam dessas riquezas, nem necessariamente aqueles onde o bem-estar das populações é mais elevado. Esses estudos levaram a maior conscientização de atores locais e decidores nacionais, conduzindo a pensar o desenvolvimento em termos de "sistemas produtivo-residenciais" de interações e de reciprocidade entre territórios (TALANDIER, 20I6) e não somente através de abordagens binárias de tais questões do tipo "modelo centro-periferia".

Em resumo, o desenvolvimento dos territórios repousa sobre três mecanismos: a) a capacidade dos territórios à criar riquezas (representada pela base produtiva); b) a capacidade dos territórios para captar rendas do exterior (representada pelas bases não produtivas); c) a circulação de riqueza e, então, a maximização da propensão à consumir localmente, que estimula o setor doméstico, determinando o nível de renda, emprego e coesão do território. Num nível micro ou meso territorial, experiências de finanças solidárias através de bancos comunitários de desenvolvimento com circulação de moeda social no Brasil, nas áreas consideradas de menor desenvolvimento, têm pautado sua prática no estímulo ao consumo local enquanto mecanismo de endogeneização da renda localmente. O intuito é de inverter a tendência de evasão de recursos financeiros que acontece quando a maior parte da popu- 
lação consome fora da sua localidade. (FRANÇA FILHO, 2OI3; RIGO; FRANCA FILHO, 2017) Num nível macroterritorial, Dowbor (2017) salienta o papel da renda e consumo das famílias enquanto motor da economia brasileira, representando mais de 60\% do nosso Produto Interno Bruto (PIB).

O terceiro eixo de ação faz referência ao princípio reciprocitário, que compreende tanto uma lógica econômica não monetária quanto abre espaço para uma circulação monetária sem fins lucrativos, a exemplo das variadas formas de mutualização de recursos financeiros. A política pública deve ajudar na estruturação de atividades, escapando à circulação monetária ou que favorecem mecanismos de apropriação democrática dos recursos financeiros. Aqui reside um inventário muito amplo e variado de possibilidades, passando por diversas formas de mutualização de recursos, de ajuda mútua, de práticas de reciprocidade enquanto mecanismos de solidariedade econômica. Seja na forma de financiamentos coletivos, passando ainda por ações de mutirões, trata-se, na maioria das vezes, de ações coletivas de auto-organização permitindo inovar socialmente na resolução de problemas concretos afetando o cotidiano da vida das pessoas e grupos. Elas indicam formas de "economia mutuária", segundo a expressão de Guerreiro Ramos (1989).

Se tais ações dizem respeito a atividades mais conhecidas desde às últimas décadas no mundo; como os sistemas de trocas locais na França, ou sua modalidade semelhante em países anglofônicos na forma de bancos do tempo - Timebanks ou Local Exchange Trade System (LETS) -, que aliás encontra outras versões na américa latina através dos clubes de trocas; elas também fazem alusão às formas ainda mais antigas em nossa realidade participando de uma tradição histórica de auto-organização do meio popular - mutirão, fundo de pasto -, como também abrem caminhos para se pensar as novas possibilidades em torno das ferramentas digitais. As novas tecnologias podem trazer uma contribuição relevante no desenvolvimento de soluções criativas em matéria de reciprocidade. Nesse âmbito, podemos citar as plataformas cooperativas, os aplicativos de compartilhamento - para deslocamento ou alojamento, entre outros - e que não entraram num circuito agressivo de 
mercado. Essas iniciativas participam do fortalecimento dos vínculos sociais e do enriquecimento da vida individual através da descoberta do outro.

Finalmente, o quarto eixo diz respeito à negociação com potenciais investidores externos. Os atores públicos, numa estratégia de instauração de territórios solidários, são convidados a rever os elementos de apreciação e critérios de avaliação das contribuições esperadas ligadas aos investidores externos. Trata-se de vislumbrar não somente os pontos positivos ligados à chegada de novos capitais, mas também todos os efeitos deletérios no plano social, cultural ou ambiental. Um tal tipo de política é preventivo por natureza e objetiva zerar qualquer efeito de externalidade negativa. Esse eixo privilegia investidores que venham para permanecer de maneira durável no território e que se engajem por consequência, assim como outras ações propondo soluções de reinvestimento local com participação ativa do agente externo enquanto um modo de refazer o próprio princípio da transferência direta ou da redistribuição. O intuito nesse eixo é de realinhar uma ação que seria característica do segundo eixo, como um complemento a esse trabalho de atração do investimento externo.

Dois exemplos na França a esse respeito parecem particularmente relevantes. No primeiro caso, uma organização como Terres de Liens promove iniciativas de aquisição e recompra de áreas de exploração agrícola locais para evitar a especulação fundiária e garantir a permanência de pequenos agricultores nas suas terras. Terres de Liens é uma rede associativa surgida em 2003, associando uma organização de economia social e solidária e uma fundação. O trabalho dessa rede encontra-se na confluência de muitos campos como a educação popular, a agricultura orgânica e biodinâmica, a finança ética, a economia solidária e o desenvolvimento rural. No segundo caso, Habitat et Humanisme é uma organização de grande reconhecimento no âmbito do trabalho de gestão de obras sociais. Sua ação principal consiste em construir, comprar ou renovar imóveis voltados para o público constituído prioritariamente por pessoas e/ou grupos socialmente excluídos. Nos dois exemplos há, portanto, uma forte dinâmica de ação de financiamento em direção a um público que encontra dificuldades de se financiar pelos mecanismos conven- 
cionais de mercado. Tal dinâmica de financiamento vem adicionar-se ao trabalho de acompanhamento e apoio técnico.

Parece que o trabalho de resolidarização das organizações pode se beneficiar amplamente dos eixos de política pública que acabamos de mencionar. Conjugados, tornam possível vislumbrar políticas de desenvolvimento solidário de territórios inteiramente originais e criativos. (EYNAUD, 20I8) Em relação às abordagens da economia plural, elas têm efeitos de médio e longo prazo que se acumulam e se reforçam mutuamente. A esse respeito, a experiência acumulada nos muitos países que praticam políticas públicas de economia solidária é particularmente interessante de explorar.

\section{RE-SOLIDARIZAR AS ORGANIZAÇÕES ATRAVÉS DA RECONCILIAÇÃO ENTRE O ECONÔMICO E O SOCIAL}

Discutimos neste capítulo como a resolidarização das organizações desenha os contornos de uma gestão substantiva. Observamos então que uma primeira característica importante dessa gestão substantiva é a busca por uma governança democrática. Uma segunda característica reside na vocação de integrar a gestão numa dinâmica de desenvolvimento territorial. Vamos agora explorar uma terceira característica através de processos de resolidarização visando reconciliar o econômico e o social. Essa reconciliação denota o caráter complexo das práticas organizacionais e/ou gestionárias contemporâneas que - para algumas delas - não se limitam mais a um propósito único, mas procuram combinar o econômico e o social. Em que consiste, então, uma reconciliação entre o econômico e o social? Como definir isso? Com qual quadro analítico podemos analisá-lo? Quais são os desafios para avançar na reconciliação?

\section{Reconciliar o econômico e o social: uma interpretação polanyiana}

O campo da sociologia econômica sempre salientou a difícil separação dos aspectos sociais na análise dos assuntos econômicos. Granovvetter (2007) mostrou que o comportamento dos agentes econômicos - de mercado 
- e, portanto, sua racionalidade, não pode ser inteiramente compreendida de modo independente da análise da estrutura social envolvendo esses mesmos atores. É assim que este autor inaugura um outro olhar sobre a dinâmica dos mercados (GRANOVETTER, 2000), abrindo um amplo espectro de pesquisas sobre o tema das redes na análise sociológica das organizações de mercado. Muito embora os avanços importantes produzidos pela sociologia econômica de mercados, especialmente enquanto alternativa às abordagens de escolha racional, sua análise salienta sobretudo a maneira como aspectos sociais influenciam condutas e comportamentos econômicos de agentes de mercado, deixando então de analisar a própria articulação das finalidades econômicas e sociais numa dinâmica organizacional para além dos agentes de mercado. O esforço analítico que aqui solicitamos necessita ir além de uma sociologia econômica dos mercados. (LÉVESQUE, 2009; SWEDBERG, 2009)

Mais recentemente, uma série de trabalhos buscaram analisar a relação entre as dinâmicas econômicas e sociais em organizações cuja ambição não se reduz ao mercado. Tais trabalhos têm, sobretudo, problematizado a realidade do fato associativo enquanto fato organizacional. Dentre essas referências, destaca-se o texto fundador de Laville e Sainsaulieu (1997) propondo uma sociologia da associação. A partir desse trabalho, as reflexões foram estendidas atéà política da associação (LAVILLE, 2015, 20I7), sua gestão (BERNET; EYNAUD; MAUREL; VERCHER, 20I6) e sua governança. (EYNAUD, 2OI5; LAVILLE; HOARAU, 2OI3)

A relevância desses trabalhos está, entre outros aspectos, na abordagem dos desafios implicados na gestão de formas de organização que estão em permanente tentativa de conciliação entre o econômico e o social, o que pressupõe reconhecer diferentes lógicas inerentes à natureza do seu funcionamento. Esses trabalhos representam, assim, um avanço importante na direção do que estamos aqui problematizando, inclusive, pelo diálogo que estabelecem com a perspectiva polanyana. É essa abordagem que permite uma compreensão mais precisa da relação entre o econômico e o social. Para além, então, de uma sociologia dos mercados e, em diálogo com uma sociologia do fato associativo, a perspectiva polanyana propõe uma antropologia do fato econômico na vida em sociedade. (POLANYI, I986, 20II) 
Para Polanyi, a análise econômica questiona o sentido da ação e sua institucionalização na vida em sociedade. Ele propõe uma visão ampla das interações econômicas, indo além do estrito perímetro das organizações de mercado. A antropologia econômica e, especialmente a perspectiva polanyana, conforme vimos no capítulo anterior, nos apresenta uma variedade de lógicas econômicas como o mercado, a redistribuição, a reciprocidade e o compartilhamento doméstico. (HILLENKAMP, 20I3) Num esforço de atualização dessa perspectiva, consideramos que a abordagem polanyana alimenta três perspectivas analíticas: a primeira, consiste em reconhecer a diversidade de racionalidades do comportamento econômico e em compreender suas especificidades; a segunda, supõe entender como essas diferentes racionalidades podem se articular e interagir sob diferentes formas de organizações ou de sistemas institucionais; e, enfim, a terceira, diz respeito ao como cada uma dessas racionalidades podem ser ressignificadas conforme, justamente, a relação que estabelecem entre si.

Da análise polanyiana sobre as formas institucionais do econômico (POLANYI, 1986) podemos concluir que a indissociabilidade entre o econômico e o social constituiu a norma da organização da vida em sociedade ao longo da história pelo simples fato de não se conhecer sistema econômico algum que fosse independente ou que não estivesse submetido às próprias regras elementares da vida social. (POLANYI, 2OII) É o fenômeno do enraizamento do econômico no social. Prevalecia a esse respeito aquilo que poderíamos designar como uma determinação social do econômico. Ou seja, quando as atividades econômicas não fazem sentido em si mesmas, mas apenas enquanto um meio para a realização de outros propósitos. É precisamente essa inversão, na forma de uma determinação econômica do social, que será conhecida apenas com o advento não do princípio do mercado em si, mas do princípio do mercado autorregulado na sua forma mais conhecida hoje como economia de mercado. (POLANYI, I986) Um movimento de tentativa de expulsão do social do interior do próprio econômico, que corresponde a transformar o social numa categoria de organização da sociedade, 
cada vez mais submetida às próprias regras e racionalidade do princípio do mercado-autorregulado. De uma condição de dissolução do econômico no social, o advento da modernidade, nos diz Polanyi, é aquele de um movimento na direção de uma separação ou autonomização da esfera econômica de mercado em relação ao conjunto das esferas que organizam a vida social. Movimento este sempre necessariamente tensionado entre enraizamento e desenraizamento, caracterizando uma dialética própria da modernidade segundo Polanyi. É precisamente essa perspectiva que nos conduz a tentar entender em tempos atuais não o problema da conciliação, entendido como uma espécie de justaposição entre o econômico e o social, mas a questão da reconciliação concebida como uma interação dinâmica entre o econômico e o social. É essa pista de trabalho que vamos seguir agora.

\section{Como analisar a relação entre o econômico e o social: proposta de grade analítica}

A análise anterior indica uma problemática fundamental ocupando a formulação desta grade analítica, que pode ser enunciada a partir da seguinte questão: sob que condições se observa, no nível da dinâmica organizacional e sua gestão, uma interação dinâmica entre o econômico e social? Ou seja, em que medidas práticas de gestão - e suas respectivas organizações - que reivindicam esse duplo propósito são capazes de produzir essa interação dinâmica, essa reconciliação ou essa dissolução do econômico no social?

O problema da reconciliação assim postulado sublinha a necessidade de reflexão em termos da racionalidade das práticas organizacionais. Para responder a essa questão, propomos uma dupla perspectiva de análise: a primeira, enfatiza o objetivo que guia a gestão; e a segunda, salienta o processo de realização da gestão. Com essa proposta de olhar, o intuito vai além de entender a relação entre lógicas econômicas e lógicas sociais apenas do ponto de vista de sua presumível relação de paridade ou de sobredeterminação de uma sobre a outra. Não se trata de tentar reconhecer sua justaposição, mas de buscar avaliar sua interação dinâmica. Dois critérios, praticamente indissociáveis, são então aqui 
mobilizados para análise dessa interação enquanto condição para avaliação da reconciliação entre o econômico e o social: a) o propósito da inciativa definindo a finalidade da gestão, de um lado; e b) o próprio modo de operar a gestão, do outro. O critério finalidade da gestão define-se segundo os princípios, diretrizes e normas que orientam a conduta ou comportamento do empreendimento ou iniciativa objeto da análise. Nesse critério, são considerados dois outros subcritérios que são a utilidade social, de um lado, e a viabilidade financeira, do outro. Considera-se aqui a utilidade social como a conduta ou comportamento do empreendimento guiado sobretudo pelos propósitos não econômicos da sua atividade, sejam eles de natureza propriamente social, cultural, ou ainda ambiental e/ou político. Segundo esse subcritério, os meios de viabilização em termos de recursos para tais objetivos não se resumem ao autofinanciamento sob condições de mercado. Já a viabilidade financeira define a conduta ou comportamento do empreendimento guiado fundamentalmente pela sua capacidade de autofinanciamento sob condições de mercado. O critério modo de operar a gestão, por sua vez, define o processo de organização, tomada de decisão e condução da gestão segundo princípios, diretrizes e normas utilizadas na dinâmica organizacional objeto da análise. Nesse critério, são considerados dois outros subcritérios que são governança democrática, de um lado, e governança tecnocrática, do outro. Entende-se por governança democrática as práticas de gestão orientadas a partir de dinâmicas coletivas fundadas em princípios de cooperação e mecanismos democráticos de condução. A governança democrática sugere um equilíbrio na relação entre economia e democracia, apontando na direção de uma relação indissociável entre a norma e o procedimento técnico da gestão, de um lado, e sua deliberação política respaldada numa esfera coletiva de decisão, do outro. Já a governança tecnocrática define-se como práticas de gestão cujo processo de organização, tomada de decisão e condução da gestão não são objeto de deliberações coletivas e se orientam, fundamentalmente, por diretrizes técnico-financeiras.

Na grade analítica proposta pela Figura 2 a seguir, temos no eixo X o critério da finalidade da gestão e no eixo Y o critério relativo ao modo de operar 
a gestão. O intuito é de tentar apreender as condições segundo as quais esteja indicada a capacidade em produzir reconciliação entre o econômico e o social na dinâmica da prática objeto da análise. No quadrante A, as organizações possuem modo democrático de operar a gestão e suas ações tem finalidade de utilidade social. No quadrante B, apesar da finalidade de utilidade social, tais práticas são gerenciadas de forma tecnocrática. No quadrante $C$, tanto possuem finalidade de viabilidade financeira quanto são gerenciadas de maneira tecnocrática. Já no quadrante $\mathrm{D}$, as organizações possuem foco na viabilidade financeira embora busquem mecanismos democráticos de tomada de decisão.

Figura 2 - Grade analítica da relação entre o econômico e o social

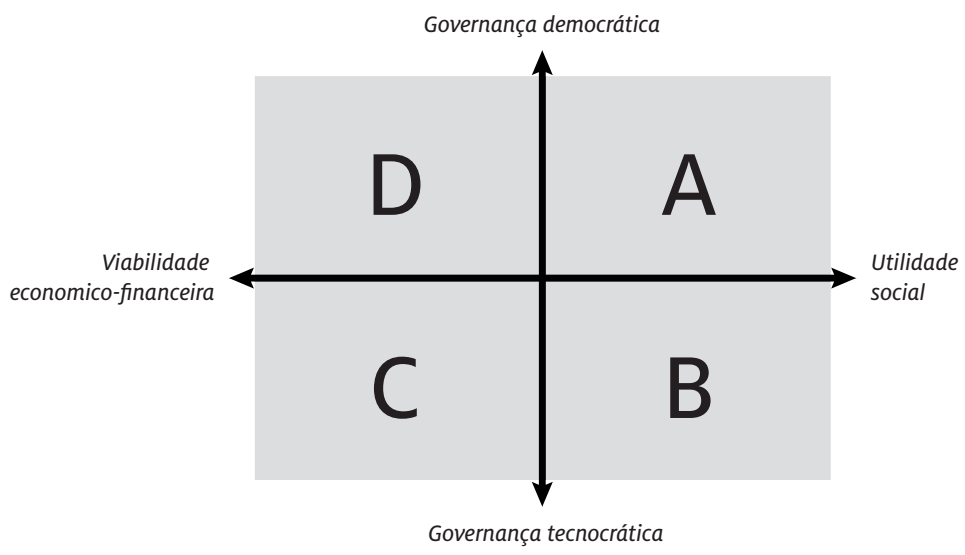

Fonte: adaptado de França Filho, Rigo e Souza (2019a).

À luz do que abordamos antes, a questão que passa a nos ocupar neste momento é aquela de saber sobre como diferentes práticas socioeconômicas desenham ou delineiam a relação entre o econômico e o social. Observamos através da discussão anterior que a reconciliação entre o econômico e social exige condições de uma efetiva indissociabilidade entre os dois termos na prática e dinâmica organizativa. É um estado de dissolução do econômico no social, caracterizando um enraizamento do econômico no social, conforme os termos polanyianos. A reconciliação se presta assim a uma lógica de determinação social do econômico, invertendo a lógica mais predominante na 
dinâmica de organizações de todos os tipos - diante do nível de influência da racionalidade de mercado em praticamente todos os campos da atividade não apenas econômica. Sugerimos então, através da grade analítica proposta, que a existência ou não da reconciliação - conforme suas condições descritas - nas práticas socioeconômicas em análise pode ser identificada através das características fundamentais da sua gestão, refletida em dois parâmetros principais que são a finalidade e o modo de condução. É, assim, a natureza da gestão que define a capacidade de reconciliação.

Detalhando então essa grade, concluímos que para haver reconciliação entre o econômico e o social deve haver uma finalidade social - ou não econômica - da gestão subordinando os imperativos de mobilização econômica dos recursos - através da viabilidade financeira - na dinâmica organizativa. Além disso, deve também haver uma forma de governança que dilua os imperativos de decisão estratégica do empreendimento num coletivo decisório mais amplo. Apenas essas duas condições reunidas indicam a reconciliação. Das duas conclusões acima conjugadas, observamos que apenas no quadrante A da Figura 2 é possível encontrar casos ou experiências de reconciliação entre o econômico e o social. Quais são então essas experiências? O que as define ou as caracterizam? Que desafios enfrentam? Já no que diz respeito aos demais quadrantes, se não se trata de reconciliação, qual desenho de relação entre o econômico e o social pode ser então caracterizado?

A literatura oferece uma ampla gama de definições que abrangem o universo das práticas socioeconômicas. Dentre estes, quatro conceitos parecem particularmente relevantes para cobrir todas essas práticas: negócios sociais; terceiro setor; economia social; e economia solidária. Sugerimos percorrer a grade de análise referindo-se a esses conceitos. Importa salientar que a dimensão do social presente nessa ideia de reconciliação indica não apenas um propósito ou finalidade não econômica, como um modo de operar a gestão que também estabeleça a primazia de critérios sociais de decisão sobre critérios apenas técnico-racionais guiados por indicadores financeiros - de rentabilidade. A ideia de critérios sociais de decisão conforma o caráter pro- 
priamente político-democrático de uma gestão concebida em outros termos, ou seja, nos termos de "uma outra gestão".

\section{A relação entre o econômico e o social na noção de negócios sociais}

O conceito de negócios sociais se popularizou a partir do trabalho de Yunus (2008b, 20I0), desde meados da década 2000. A discussão brasileira relaciona estreitamente a ideia de negócios sociais com a noção de empreendedorismo social e empresa social. (FISCHER; COMINI, 2OI2; OLIVEIRA; VASCONCELOS, 2OII; TISCOSKI; ROSOLEN; COMINI, 2OI3) Além disso, ela muitas vezes se confunde também com as noções de responsabilidade social, negócios inclusivos e, mais recentemente, negócios sociais de impacto. (LIMEIRA, 20I5) $\mathrm{Na}$ origem da noção de negócios sociais, em Yunus (2008b, 2010), o conceito é abordado a partir das seguintes características: tem a missão de atender às demandas dos segmentos populacionais de baixa renda e mais vulneráveis; desenvolve e comercializa produtos e serviços ajustados a essas demandas sociais; gera receita suficiente para cobrir as próprias despesas; reinveste uma parte do excedente econômico na expansão do negócio, enquanto a outra parte é mantida como reserva para cobrir despesas inesperadas; tem investidores que não recebem lucros na forma de dividendos, mas podem receber de volta o investimento após um período. (LIMEIRA, 2015)

Em síntese, para Yunus (20I0), um negócio social deve ter a vocação para resolver um problema social. Um tal negócio, segundo ele, pode gerar excedente, mas o mesmo deve ser reinvestido no próprio negócio e não ser apropriado por alguém ou um grupo. Nesse sentido, a noção de negócio social em Yunus diferencia-se sutilmente da tradição anglo-saxônica ao enfatizar a demanda na chamada "base da pirâmide". Nessa concepção, o mercado é definidor do que vem sendo caracterizado como negócio social. É assim que Gattes e Kiviat (2008) salientam que o que devem fazer os negócios sociais é trazer as pessoas que estão longe do sistema capitalista para dentro dele. 
Retornando ao debate brasileiro sobre essa noção, de fato, as definições mais conhecidas parecem refletir uma tendência de entendimento do tema tal como ele se difunde na matriz anglo-saxônica pensada enquanto social business. Um breve levantamento da literatura brasileira feita por Limeira (2015) indica com clareza o modo principal de compreensão do termo. Em Comini (2OII apud LIMEIRA, 20I5) por exemplo, "a empresa social (social enterprise), o negócio inclusivo (inclusive business) e o negócio social (social business)" são alguns dos termos usados para identificar as organizações que "visam solucionar problemas sociais com eficiência e sustentabilidade financeira por meio de mecanismos de mercado". Em Naigeborim (20II apud LIMEIRA, 20I5) também se enfatiza os mecanismos de mercado: "estes negócios devem funcionar sob as mesmas regras comerciais de qualquer outro negócio, isto é, operar pela lei da oferta e demanda do mercado". Segundo a autora, esses empreendimentos são planejados a fim de gerar os recursos suficientes para cobrir a totalidade de suas operações e ainda contribuir para seu crescimento. Porém, nesses negócios "o lucro não é um fim em si mesmo, mas um meio para desenvolver soluções que ajudem a reduzir a pobreza, a desigualdade social e a degradação ambiental". Nessa mesma linha argumentativa, Oliveira e Vasconcellos (20II, p. 7) consideram que negócios sociais e inclusivos são modelos de empreendedorismo que geram impactos sociais, devendo ser economicamente rentáveis. Para os autores, não é necessário escolher ser rentável e provocar transformação social, pois ambos são concomitantemente possíveis. A autossuficiência e a rentabilidade também são aspectos fundamentais para a concepção institucional brasileira sobre negócios sociais.

Por essas definições, os negócios sociais estariam indicando a capacidade dos empreendimentos em, sobretudo, gerar autossuficiência econômico-financeira sob condições de mercado e ainda atender supostas demandas sociais. Assim, os negócios sociais se definem como empreendimentos viáveis economicamente, residindo precisamente nessa viabilidade sua capacidade em atender ao social. Entretanto, a literatura se revela carente de 
estudos de caso que permitam evidenciar empiricamente como os negócios sociais compatibilizam viabilidade econômico-financeira com atingimento de finalidade social. Faltam balanços e demonstrativos contábeis. Restam, de todo modo, algumas indicações sobre os casos que estariam sustentando o conceito assim formulado. Uma breve avaliação da grande maioria dos casos brasileiros citados como exemplos de negócios sociais, nos leva a apontar pelo menos três conclusões:

a. entende-se por negócios sociais, a rigor, a experiência de um tipo de empreendedorismo privado que explora um público constituído por segmentos populacionais considerados de baixa renda. A qualificação de social seria então definida pelo seu nicho de negócio e aqui, inventa-se uma nova categoria de marketing: o social como um novo nicho de mercado. Num dos exemplos mais conhecidos, o negócio consiste na oferta de serviço de reparo de moradias em favelas a um custo considerado inferior a média de mercado. Permanece neste caso ainda em aberto a questão sobre como se define a baixa renda e até onde a atividade "se paga";

b. entende-se por negócios sociais também o fato dos seus agentes se constituírem como empresas privadas - como no caso anterior -, porém sem explorar um nicho específico de mercado. A novidade neste caso residiria no fato da iniciativa admitir algum grau de repasse - voluntariamente decidido pela empresa - dos recursos obtidos ou gerados junto a um público considerado social. Num exemplo muito conhecido, uma empresa de vestuário, cuja marca volta-se para um público de renda elevada, doa um certo percentual equivalente de peças de roupas para a população carente - através de acordos firmados com instituições de caridade -, conforme o montante de suas vendas;

c. um terceiro grupo de casos apontados na literatura é bastante surpreendente ao se distinguir do caráter de moralização do capitalismo ou filantropização do negócio presente nos dois primeiros tipos: trata-se de um seleto grupo de organizações da sociedade civil empreendendo práticas inovadoras. Aqui, o discurso dos negócios sociais toma emprestado exemplos conhecidos de organizações da sociedade civil que se reivindicam participando de outras agendas em 
termos de movimentos sociais, como no caso do Banco Palmas que se autodefine como uma prática de economia solidária.

\section{A relação entre o econômico e o social na noção de terceiro setor}

Terceiro setor é uma noção oriunda da realidade norte-americana e testemunha grande proximidade com a ideia de filantropia. Num contexto em que não há tradição de estado social, o termo reagrupa as organizações do chamado voluntary sector ou non-profit sector. Muito embora o terceiro setor não reivindique uma dimensão socioeconômica específica, pode-se deduzir tal dimensão do fato das organizações do terceiro setor se dotarem de objetivos claramente não econômicos, de um lado, e empreenderem ações de mobilização de recursos no cumprimento desses mesmos objetivos enquanto estratégia de ação, por outro. Salomon e Anheier (1992) consideram, que neste campo as organizações apresentam cinco características essenciais: elas são formais, privadas, independentes, não devem distribuir lucros e devem comportar um certo nível de participação voluntária. Duas outras características são excluídas: as organizações não devem ser nem políticas e nem confessionais. É com base nesta caracterização que foi forjada a nomenclatura comum e mais antiga de classificação do terceiro setor, conhecida pela International Classification of Non-Profit Organizations (ICNPO). Foi justamente essa nomenclatura que serviu de base à pesquisa internacional sobre o terceiro setor dirigida pela Fundação John Hopkins, no início dos anos I99o, que compreendeu I3 países, incluindo o Brasil. Ao deixar de fora o critério da informalidade, essa abordagem acaba ignorando um amplo inventário de iniciativas desempenhando um papel essencial para uma grande parte da população em países latino-americanos. Doravante, a noção foi bastante criticada por inúmeras organizações da sociedade civil envolvidas nos movimentos sociais.

Se a exportação do termo terceiro setor em direção aos países do sul não parece particularmente pertinente, a generalização da sua utilização - sobretudo nos países do sul - testemunha o estabelecimento de uma relação de 
dominação. Segundo a interpretação dominante na literatura anglo-saxônica, a existência de um terceiro setor está ligada a certas imperfeições do mercado - notadamente as assimetrias de informações - e às necessidades de satisfazer as demandas de grupos minoritários - não cobertos pelo Estado. Do ponto de vista da prática organizacional, a noção de terceiro setor carrega implicitamente uma ênfase sobre a realização de objetivos sociais. Muitas organizações do setor não lucrativo adotaram normas tecno-burocráticas e procedimentos de gestão formal. Atualmente, assiste-se inclusive uma reaproximação conceitual dos termos terceiro setor e negócios sociais quando as primeiras são impelidas a gerarem seus próprios recursos segundo relações de mercado convencionais. Em resumo, a ideia implícita ligada à noção de terceiro setor supõe o estabelecimento de uma equação específica combinando um objetivo de utilidade social e uma governança tecnocrática.

\section{A relação entre o econômico e o social na noção de economia social}

Diferentemente da noção de terceiro setor - tipicamente norte-americana -, a noção de economia social remete ao contexto europeu de realidade. Neste, a relação com o Estado social é constitutiva das experiências associativistas, conforme nos lembra Laville (2000). Nesse sentido, a ideia do terceiro setor na Europa, para este autor, requer ir além do seu entendimento como um segmento suplementar da economia, para vislumbrá-lo mais como uma dinâmica em interação histórica permanente com os poderes públicos. É precisamente essa herança histórica que distancia ainda mais a noção de economia social - juntamente com a noção de economia solidária que possui origem comum - em relação à noção de terceiro setor. Trata-se de uma tradição histórica identificada com o movimento associativista operário da primeira metade do século XIX na Europa. Nesse período, a Europa conheceu a emergência de um grande número de experiências de autoajuda e de socorro mútuo no seio das populações de trabalhadores. Essas experiências foram formalizadas entorno de três tipos organizacionais: as cooperativas, as associações e as organizações mutualistas. Tais 
inovações organizacionais foram fruto de experiências operárias visando autonomia e transformação social, na contramão da doutrina marxista que defendia a centralização estatal. A expressão "socialismo utópico" foi então proposta por Engels para caracterizar tais experiências, cujo intuito fora desacreditá-las ao opor o termo "socialismo científico". Grande parte da população na Europa encontrava-se em condições de grande pobreza neste período. As iniciativas populares de organizações mutualistas nascem em condições muito difíceis pois não possuíam caráter legal. A lei buscava até mesmo evitar a constituição desse tipo de experiências de compartilhamento e cooperação no seio da classe operária.

No entanto, o papel e a contribuição dessas iniciativas acabaram por se impor, e essas inovações sociais ganharam gradativamente o reconhecimento dos poderes públicos. Estatutos jurídicos específicos se consolidaram progressivamente ao longo da segunda metade do século XIX e início do século XX. Essa normalização tardia vai permitir aos atores da economia social de se integrar no sistema econômico dominante. As cooperativas vão, então, participar da economia de mercado ocupando "zonas de atividade onde a intensidade de capital permanecia fraca". (LAVILLE, 2000, p. 532) As organizações mutualistas vão se fortificar e se banalizar. Os primeiros quadros militantes de tais organizações são progressivamente substituídos por profissionais dotados de uma forte cultura tecnocrática. A dimensão técnica ou funcional de tais organizações acaba primando sobre o projeto político inicial. Assim, o desenvolvimento da economia social é acompanhada da sua institucionalização ao longo do século XX. As organizações de economia social se banalizam e um grande número dentre elas adotam funcionamentos muito próximos das empresas mercantis com as quais elas acabam por se encontrar em concorrência.

Em resumo, e como consequência histórica, a perspectiva de uma economia social e solidária se enfraquece então num primeiro e longo momento. No seu lugar, dissemina-se uma economia social que se torna altamente institucionalizada ao longo do século XX e cujo papel vai se limitando ao de um apêndice do Estado. As organizações da chamada economia social hoje, em inúmeros países, a exemplo da França, passam a representar grandes es- 
truturas tecnoburocráticas que dificilmente se distinguem, na sua dinâmica de funcionamento, de uma empresa privada ou pública. Diante disso, uma dinâmica complexa tenta reanimar esse campo cooperativista nos últimos anos em diversos países, a exemplo do Brasil, quando muitas iniciativas atuais buscarão reabilitar seus princípios históricos em nome de uma forte preocupação com a maior democratização de suas formas de organização. O campo vai encontrar-se assim ainda mais heterogêneo e muitas dessas novas cooperativas serão fortemente marcadas pela tensão entre, de um lado, as exigências e pressões de mercado para realização da sua dimensão econômica e, do outro, seu esforço em tentar aprofundar seus mecanismos de governança democrática.

\section{A relação entre o econômico e o social na noção de economia solidária}

O conceito de economia solidária se construiu em torno de um amplo espectro de experiências de auto-organização e de autogestão oriundas da sociedade civil e dos meios populares. Para os atores da economia solidária na Europa, trata-se de retornar a ambição inicial dos atores do movimento associacionista (CHANIAL, 2OIO) desde a primeira metade do século XIX, ou seja, democratizar a economia. (LAVILLE; SALMON, 20I6) Vinculadas aos movimentos sociais, tais iniciativas afirmam uma forte dimensão política. (LAVILLE, 20Io) Na disseminação do conceito de economia solidária no Brasil, ao menos três origens e influências específicas merecem ser destacadas. Uma primeira influência encontra-se nos próprios estudos sobre o tema empreendidos por autores nacionais, cujo marco de referência são os trabalhos de Paul Singer desde o final dos anos 1990. Uma segunda influência são os trabalhos de autores latino-americanos sobre o tema da solidariedade na economia, como o chileno Razeto nos anos I970 ou o argentino Coraggio nos anos I980. Já a terceira, influência se encontra em alguns trabalhos de estudiosos europeus, com especial destaque para a contribuição de Laville na França desde o seu livro seminal de 1994. Essas diferentes influências trazem em comum uma preocupação em refletir sobre práticas de organização socioeconômicas que são gestadas no in- 
terior das sociedades numa afirmação crítica em relação aos fundamentos da racionalidade capitalista predominante.

No Brasil, de fato, o conceito de economia solidária intenta compreender uma grande variedade de inciativas de auto-organização socioeconômica partindo da sociedade civil e dos meios populares. Tais iniciativas revelam-se relativamente diversas no que diz respeito à área de atuação, modo de estruturação, natureza jurídica e grau de abrangência da prática, entre outros aspectos. Também chamada de economia popular e solidária, essa designação indica um campo institucional em processo de formação. (FRANÇA FILHO, 2006a) Neste, quatro instâncias principais o conforma: as inciativas socioeconômicas ou Empreendimentos Econômicos Solidários (EES); as entidades de Apoio e Fomento (EAFs) que são organizações de suporte aos EES como incubadoras de economia solidária ligadas às universidades ou organizações da sociedade civil; as formas de auto-organização política como os variados fóruns e redes de economia solidária em múltiplos níveis e escalas; e as instâncias políticas governamentais como secretarias, orgãos ou departamentos presentes em diferentes governos. (FRANÇA FILHO, 2006a)

No coração desse universo de experiências, os EES têm sido definidos a partir de cinco características fundamentais: a) são sociedades de pessoas, e não sociedades de capital - como as empresas privadas -; b) ao associar pessoas assumem, originalmente, função social, e, assim, a função mercantil é a ela subordinada, dela dependente; c) são associações de pessoas iguais e isso exige relações de poder paritárias com processos de tomada de decisão horizontais, dialogados e constituídos por consensos; d) a propriedade dos meios de produção é coletiva, assim como a apropriação do resultado econômico; e) o trabalho dos sócios não é assalariado. Ao contrário, nos ESS o trabalhador é, ele próprio, proprietário, tanto dos meios de produção, quanto do resultado econômico e da força de trabalho.

De fato, um dos traços característicos mais salientados tanto nas diferentes definições de EES quanto nos discursos dos sujeitos que atuam em tais iniciativas diz respeito à natureza autogestionária desses empreendimentos. Evidentemente que a autogestão é vivida na prática dos EES como um pro- 
cesso de aprendizagem de uma cultura política de governança democrática e enquanto tal apresenta avanços maiores ou menores, conforme os diferentes casos refletidos no grau de maturação de cada experiência. Esse aspecto confere um conteúdo político particularmente importante no entendimento da ação e propósito da economia solidária, ressignificando o modo como os sujeitos concebem o trabalho em tais iniciativas.

De fato, o trabalho na economia solidária adquire outros significados para além da produção econômica em si. É como se atividade econômcia fosse diluída em outros sentidos ou servisse como um meio para outros objetivos. Para Max-Neef (20I2), a dimensão econômica é um meio pois o trabalho - na economia solidária - preenche necessidades existenciais de ter, ser, fazer e estar não exclusivamente econômico-monetárias. A diluição da atividade produtiva em outros propósitos também pode-se observar para fora da ação organizacional em economia solidária, quando suas práticas são compreendidas como novas modalidades de ação pública num dado contexto local territorial (FRANÇA FILHO, 20I3), isto é, quando EES através da sua dinâmica socioeconômica, estão respondendo por demandas de afirmação identitária, de preservação ambiental, de valorização de vínculos sociais ou de fortalecimento de lutas políticas - pelo acesso à terra, pela alimentação saudável e livre de agrotóxicos, pelo direito à moradia, à cidade, pela emancipação feminina etc.

É assim que o campo dos EES compreende um amplo e difuso inventário de experiências com seus respectivos públicos diversificados. Da economia solidária no Brasil participam pessoas com transtornos psicossociais - em tratamento de saúde em Centro de Atenção Psicossocial (Caps) do Sistema Único de Saúde (SUS), presidiários cumprindo pena em centros de detenção, donas de casa - em clubes de mães e associações comunitárias e de moradores -, trabalhadores da agricultura familiar, assentados da reforma agrária, quilombolas, nativos de florestas, pescadores, indígenas, artistas, catadores de material reciclável, profissionais, técnicos e especialistas do setor de serviços - a exemplo de Associações de Aassistência Técnica e Extensão Rural (Ater) -, além de todo o segmento de pessoas em situação de desemprego/ desocupação, incluindo população em situação de rua. Junto a tais segmen- 
tos atuam incubadoras universitárias, organizações da sociedade civil e, em alguns casos, gestores públicos.

Os EES são também organizações distintas em termos de status, motivação para constituição e capacidades. São coletivos formais, informais, em vias de formalização ou em estágio de mudança de natureza - por exemplo, de associação para cooperativa. Têm origens, entre outros espaços e motivações, em clubes de mães, organizações comunitárias, na necessidade de controle pelos trabalhadores de empresa em estágio falimentar, na necessidade de capitalizar uma atividade produtiva, de fortalecer processos de compra de matéria-prima e insumos ou de fortalecer comercialização coletiva e de promover capital social e bem-estar de indivíduos e comunidades. Os EES são, ainda, organizações em estágios diversos de maturidade em termos de práticas autogestionários. Nesse quesito, merece destaque o fato de que, entre os EES existem aqueles com processo autogestionário definido e maduro, com práticas nítidas de decisão dialogada, transparência e ampla participação dos membros no processo de tomada de decisão, o que favorece a rotatividade na gestão e na liderança do coletivo. Em estágio intermediário, há empreendimentos que cultivam a participação dos membros, exercem transparência nos processos de tomada de decisão e gestão, mas, carecem de paridade no exercício do diálogo interno e na renovação de liderança. Não raro, são empreendimentos com membros em estágios diferentes de engajamento sociopolítico na comunidade e de compromisso com movimentos sociais, ou, com níveis de escolaridade distintos. Nesse caso, é facilmente constatada certa centralização de autoridade e poder no líder - que, por vezes, deseja que ocorra a rotatividade, mas, os próprios membros insistem em mantê-lo na direção, uma vez que o tomam como referência.

Os ESS são organizações constituídas por públicos distintos mediante propósitos e motivações diversos - de geração de renda, de complementação de renda familiar e, concomitantemente, de utilidade social - o que pode ser explicado a partir do segmento sociodemográfico dos trabalhadores. Defendemos que propósitos de geração de renda ou de complementação de renda e, na outra ponta, de utilidade social, têm relação direta com o perfil do públi- 
co envolvido e sentidos que os membros atribuem à atividade associada que desenvolvem. Essa leitura ajuda a compreender por que em muitos desses casos empreendimentos revelam-se sustentáveis, em função da sua importante longevidade, mesmo obtendo baixo rendimento econômico-financeiro. (SINAES, 2OI3)

\section{As condições da reconciliação}

Num esforço de aplicação da nossa grade analítica proposta (ver figura 2) aos quatro casos que acabam de ser analisados, temos a Figura 3 a seguir. Nesta, identificamos três resultados diferentes em resposta à questão fundamental sobre em que medida práticas então designadas como socioeconômicas são capazes de produzir a reconciliação entre o econômico e o social. Os três resultados que serão interpretados a seguir são: a não reconciliação, a conciliação ou justaposição e a reconciliação.

Figura 3 - Tipologia da relação entre o econômico e o social

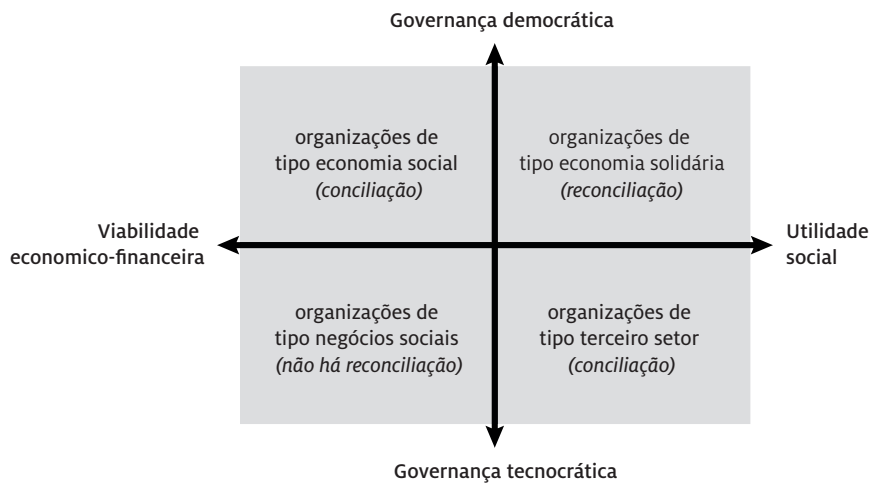

Fonte: adaptado de França Filho, Rigo e Souza (2019).

Verificamos a não reconciliação entre o econômico e o social no caso dos negócios sociais, pelo fato de tanto sua finalidade quanto seu modo de gestão encontrarem-se fundados em lógicas de separação do econômico em relação ao social. É assim com a primazia do enfoque da viabilidade financeira enquanto finalidade da ação organizacional. Os aspectos sociais nesse caso 
são compreendidos como um efeito induzido ou colateral da atividade econômica. Os ganhos econômicos seriam então capazes de proporcionar, indiretamente, o atingimento da finalidade social, que aparece muito imprecisamente definida: um serviço a preço supostamente mais acessível à população considerada de baixa renda, doação de produtos do próprio negócio aos mais necessitados conforme volume de vendas etc. Do mesmo modo, em relação à governança, o empreendimento deve obedecer aos padrões rígidos de uma racionalidade tecnocrática considerada como condição para a eficiência do propósito organizacional. Reafirmando a compreensão do econômico conforme os mecanismos, princípios e valores mais característicos da racionalidade de mercado, os negócios sociais sacramentam a separação radical do econômico com o social.

Entre a não reconciliação e a reconciliação encontramos duas situações intermediárias, que aqui iremos definir como de conciliação ou de justaposição entre o econômico e o social. Entende-se por conciliação a coexistência justaposta do econômico e do social num mesmo projeto organizacional. Essa coexistência não permite o fusionamento - que levaria ao estado de reconciliação -, pois o econômico e o social nesse caso respondem por racionalidades muito opostas.

No caso do terceiro setor, o estado de conciliação que se observa se apresenta no sentido inverso do caso da economia social. O social está representado pela finalidade de utilidade social característica das organizações sem fins lucrativos, que historicamente não encontram na lógica da geração de recursos próprios, segundo o mecanismo da contraprestação financeira de produtos ou serviços comercializados, o foco principal da sua captação de recursos. Contudo, isso não conduz necessariamente à assimilação de processos de governança democrática. Muito pelo contrário, a grande maioria das organizações sem fins lucrativos adota os formatos mais convencionais de gestão tecnocrática ao ter como espelho de referência os modelos de gestão característico da administração de empresas. 
Além disso, a literatura predominante sobre o terceiro setor não enxerga na democracia organizacional um elemento central ou estratégico para o cumprimento dos seus propósitos. E ainda, com a reconfiguração do atual cenário de financiamento das organizações da sociedade civil, cresce a dependência em relação aos financiadores privados, do mesmo modo que aumenta o número de tais organizações vinculadas ao setor privado - fundações empresariais, responsabilidade social corporativa etc. -, fazendo com que ocorra maior tendência de aproximação desse tipo com aquele dos negócios sociais. Muitas organizações sem fins lucrativos são agora convidadas a desenvolverem seu próprio portifólio de serviços a serem comercializados. Na resistência ou contra movimento, não podemos deixar de reconhecer os casos de baixa intensidade da governança tecnocrática em certas organizações da sociedade civil que embora fundem sua gestão em regras rígidas admite certo grau de democratização das decisões, caminhando na direção de sistemas mais isonômicos.

No caso da iniciativas de tipo economia social, especialmente refletida na realidade das organizações cooperativistas de porte mais elevado, admite-se o foco no resultado econômico através da busca da viabilidade financeira do empreendimento também compreendido como um negócio, mas, ao mesmo tempo, busca-se favorecer maiores níveis de participação na gestão através da valorização de mecanismos de governança democrática. É preciso, no entanto, reconhecer os diferentes graus de intensidade relativos a cada um dos quatro subcritérios. Em algumas cooperativas, por exemplo, pode-se observar baixa intensidade no foco da viabilidade financeira, com reafirmação do princípio contábil da sobra e maior valorização dos princípios históricos do cooperativismo que inclui a importância do desenvolvimento comunitário. Nesse tipo de situação, a finalidade organizacional se aproxima do quadrante da utilidade social. Em contraste, outros exemplos de cooperativas são reveladores de baixa intensidade na sua governança democrática e maior aproximação dos mecanismos tecnocráticos de gestão, que costumam ser acompanhados também de maior intensidade de foco na viabilidade financeira e distan- 
ciamento da utilidade social na finalidade do empreendimento. Isso ocorre frequentemente nos casos de cooperativas que assimilam seu funcionamento à forma de empresas diante de pressões ambientais do seu setor de atividade característico de processos de isomorfismo institucional.

Finalmente, pode-se observar uma efetiva propensão à reconciliação entre o econômico e o social nos casos de economia solidária. Diferentemente de uma coexistência ou justaposição das duas dimensões, a reconciliação é compreendida como uma efetiva interação, envolvimento e/ou enraizamento do econômico no social. A natureza econômica do empreendimento torna-se indissociável de sua prática social, política, cultural ou ambiental. Duas características da dinâmica econômica incidido na prática organizacional costumam indicar a reconciliação: a) o descentramento do mecanismo de mercado na mobilização de recursos, ensejando a emergência de práticas mais colaborativas na gestão, com um maior apelo a princípios de solidariedade econômica, como a redistribuição e a reciprocidade; b) a ressignificação da própria prática de mercado na dinâmica do empreendimento, quando são introduzidos mecanismos de cooperação e solidariedade na conformação das suas relações de mercado através de pactos, acordos, arranjos e redes interatores de diferentes tipos e formas, apoiadas em valores e princípios tais como o comércio justo, as finanças solidárias, o consumo ético e consciente, entre outros. As condições para o efetivo exercício da reconciliação são também definidas pelo contexto territorial. EES não se definem independente do seu território de pertencimento.

O sentido da atividade econômica empreendida não se compreende sem uma relação com as condições sociais e história de vida das pessoas que dele participa, sua relação de identidade cultural com o lugar onde se situa. Frequentemente, EES se definem como agentes de desenvolvimento do seu território. O substrato econômico-material da atividade realizada pelo empreendimento não se compreende sem uma motivação de outra natureza que anima e conduz o projeto organizacional. Além disso, a busca pela autogestão das iniciativas pode ser vista como um esforço permanente de aprendizado 
de um processo de governança democrático concebido como um princípio primordial da gestão. Refletindo sobre a questão da intensidade, observa-se entre os EES níveis variados de governança democrática conforme o grau de maturidade das iniciativas definido pela sua capacidade de aprendizagem, isto é, de mudança cultural.

Os quadrantes apresentados na Figura 3 apenas sinalizam um horizonte de possibilidades para cada contexto e realidade das iniciativas socioeconômicas na sua capacidade em desenhar diferentes formas de relação entre o econômico e o social. No entanto, esse panorama não é rígido ou estático, pois deve-se estar atento a diferentes trajetórias que podem ser observadas em cada quadrante. Ou seja, a intensidade com que se apresenta - em cada caso - cada um dos quatro indicadores relativos à finalidade e modo de operar a gestão define mais claramente o posicionamento estratégico do empreendimento. Essa posição ou "lugar" do empreendimento nos ajuda a melhor compreender seus desafios, seja do ponto de vista da natureza dos conflitos que o caracteriza, seja em termos do alcance estratégico de suas ações para a transformação almejada. São, portanto, nessas intensidades respectivas que vai se traduzir, com maior ou menor força, a não conciliação, a justaposição ou a reconciliação. Essa grade analítica pode ser vista então como um apoio para situar cada iniciativa diante de suas ambições e desafios próprios. Podemos concluir, em termos conceituais, que a reconciliação apenas consegue se exprimir através de um reenraizamento do econômico no social. Ora, nos marcos de uma relação econômica de mercado convencional não há margem de manobra para a reconciliação. A condição para tanto está no fato da prática organizativa efetivamente absorver princípios e lógicas de uma outra economia. Ela requer a expressão de uma governança democrática e a afirmação da utilidade social como finalidade.

Como esforço de síntese teórica da reflexão proposta neste tópico, anunciamos em resumo três conclusões que nos parecem particularmente fecundas:

a. em contextos de determinação econômica do social, torna-se inconcebível uma reconciliação do econômico e do social. Logo, segundo 
os parâmetros e racionalidade convencionais do mercado não é possível operar essa reconciliação;

b. a reconciliação do econômico e do social pressupõe a ativação de dispositivos e mecanismos institucionais pressupondo não apenas a combinação de lógicas econômicas variadas, como a ressignificação dos princípios e práticas de mercado;

c. A reconciliação do econômico e do social pressupõe a institucionalização de um outro tipo de economia. Esse outro tipo de economia parece revelador de uma síntese histórica do passado com o presente bastante inspiradora ao, simultaneamente, apontar soluções inéditas para problemas contemporâneos e estar apoiado em princípios de organização econômica muito antigos, já que estes últimos remontam aos tempos em que a imbrincação entre o econômico e o social era parte inerente da natureza do próprio econômico - definido em seu sentido substantivo, como nos ensina a antropologia econômica.

Para finalizar esta parte, é importante especificar que a realização da reconciliação requer ainda uma dinâmica de aprendizagem e compartilhamento que não acontece sem uma série de desafios face à questão da sustentabilidade das iniciativas. A questão, então, é aquela de saber sobre: a) como operar, em termos práticos, o processo de reimbrincação, reenraizamento ou reintegração entre o econômico e o social; e b) nestes termos, como então a sustentabilidade se define. Levando-se em conta que essa reintegração é a condição de uma abordagem substantiva da economia, o problema da desmercadorização das mercadorias fictícias deve ser levantado e refere-se à construção prática da outra economia. Isso envolve uma reflexão em torno da organização de um processo de desmercadorização do ser humano, da moeda e da natureza.

\section{RE-SOLIDARIZAR AS ORGANIZAÇÕES ATRAVÉS DA REIMBRICAÇÃO DAS MERCADORIAS FICTÍCIAS}

Após o fim da Segunda Guerra Mundial, a Declaração da Filadélfia reconheceu a necessidade de um novo modelo econômico que priorize o desen- 
volvimento social. A economia era, portanto, vista como um meio a serviço da sociedade. Na esteira dessa declaração, as políticas econômicas regulatórias keynesianas acompanharam um longo ciclo de crescimento de 30 anos gloriosos. Esse período foi acompanhado pelo desenvolvimento de um estado de bem-estar social que permitiu a disseminação dos sistemas públicos de proteção e seguridade social - saúde, previdência e assistência - em muitos países. Durante esse período, as organizações da economia social - associações, cooperativas, organizações mutualistas - consolidaram-se, mas não tiveram capacidade para ter impacto político. Essas organizações foram banalizadas e em grande parte postas em concorrência com as empresas capitalistas. Isso resultou na obrigação de seguirem as mesmas regras de precaução e adotarem os mesmos padrões ou normas. Essa extensão da economia de mercado para além de suas fronteiras foi construída em torno da promoção da mercadoria e da "sociedade do espetáculo". (DEBORD, I996) A transformação de uma economia de mercado em uma sociedade de mercado tornou difícil, se não impossível, afirmar uma sociedade consciente dela mesma. (JAPPE, 2003) Como resultado, esses anos de forte crescimento econômico vieram com o custo da adoção de pesticidas na agricultura, a implantação da indústria nuclear e a exploração abusiva dos recursos naturais do planeta. Os 30 anos gloriosos (I945-I975) também foram devastadores. (PESSIS; TOPÇU; BONNEUIL, 2OI5) Devoradores de energias - energívoros -, iniciaram a era do desperdício, desenvolveram a ideologia produtivista invisibilizando as vítimas de diferentes poluições industriais. A descolonização não eliminou as desigualdades entre os países nem permitiu a generalização das democracias.

No entanto, os movimentos de libertação em países do Sul tiveram como corolário o recrudescimento de novos movimentos sociais no norte: feminismo, insubordinação, ecologia. Assim, uma nova reflexão pôde aparecer e favorecer o nascimento de novas propostas econômicas voltadas para a transformação do sistema a partir do interior. Através da busca por um preço justo e o apoio as redes de produtores e de consumidores, iniciativas relevantes como o comércio justo, os circuitos curtos - como associações para a ma- 
nutenção da agricultura camponesa -, as moedas sociais puderam aparecer. Vamos agora detalhar como essas iniciativas produziram modos de organização suscetíveis de responder aos desafios de gestão levantados pela mercadorização do mundo e iniciar um processo de reintegração ou reimbricação das mercadorias fictícias identificadas por Polanyi, ou seja, o trabalho, a moeda e a natureza.

\section{Cooperativa de atividade e desmercadorização do trabalho}

Para Weber, "colocar o trabalho a serviço de uma organização racional que fornece à humanidade seus bens materiais sempre apareceu aos representantes do espírito do capitalismo, incontestavelmente, como um dos objetivos de sua tarefa". (WEBER, I964; p. 78) A partir daí, o gerenciamento científico de Taylor responde a uma tarefa eminentemente primordial. Ele não é um método como outro qualquer, mas o modo de pensamento da gestão. (COUTROT, 20I8) Drucker não está enganado. Ele diz sem hesitação que a administração científica é mais do que uma filosofia de trabalho. Segundo ele, essa é a contribuição mais importante da América para o Ocidente depois da contribuição dos pais da Constituição. (DRUCKER, 1954) Embora a ideia possa provocar risos, não se pode negligenciar as forças econômicas que apoiam tal posição. Se faz necessário então concordar com Drucker que a questão é importante e que é preciso empreender uma análise crítica da dimensão científica da abordagem.

Conforme salienta Braverman, a gestão científica do trabalho é menos preocupada com o trabalho do que com sua adaptação sem limites às necessidades do capital. (BRAVERMAN, I998) A gestão científica tem a missão essencial de garantir que "o trabalhador se adapte ao seu trabalho" (BOUQUIN, 20Io, p. I64), sem jamais vislumbrar a solução oposta. Assim, os trabalhadores estão sujeitos a "uma perpétua instabilidade, à uma modulação permanente". (ALLARD-POESI, LOILIER, 2009, p. 7) Trata-se para Taylor, conforme revela Postone (2009), de controlar o desempenho do trabalhador com a ajuda de um cronômetro para tornar a entrega do trabalho objetiva. O desafio é, na 
verdade, substituir "o trabalho vivo pelo trabalho morto [...] se não por categorias de mão de obra mais dóceis". (BOUQUIN 20IO, p. I77) Por trabalho morto entende-se aqueles das máquinas, ou de homens transformados em máquinas - como mostra brilhantemente o filme Tempos Modernos, de Chaplin.

Assim, o pensamento tecnocrático "transformou os problemas sociais em problemas técnicos". (CHANLAT, 20I3, p. 8) Mais fundamentalmente, a administração científica se sente enfraquecida quando ela deixa ao trabalhador o poder de decisão. (BRAVERMAN, 1998) Braverman enfatiza que "se os economistas admitem que os objetos são fabricados por seres humanos", eles esquecem entretanto que estes mesmos humanos são, eles próprios, "fabricados". (BOUQUIN, 20IO, p. I64) Em outras palavras, os economistas - juntamente com os defensores do gerenciamento científico - negligenciam as construções sociais. O mercado - com a ajuda da concorrência que ele promove - é responsável pela destruição de solidariedades, opondo os empregados entre eles. (ALLARD-POESI; LOILIER, 2009) Existe uma conivência entre os dois tipos de gestão científica promovida por Taylor e Mayo. O primeiro é responsável pelo desempenho da produção de bens e serviços e o segundo, pelos danos causados pelo primeiro. (BRAVERMAN, I998) O primeiro responde às necessidades da guerra econômica, o segundo procura tratar os feridos.

Assim, o taylorismo não está morto. Ele renasce constantemente de suas cinzas com a chave para novas precariedades. A uberização é uma representação contemporânea. Para Feher (20I7), essa figura testemunha um deslocamento da questão social. O crescimento significativo do número de trabalhadores independentes - autoempreendedores - é representativo dessa mudança. Ela consiste em transformar, através do jogo da externalização de atividades - terceirização -, empregos que se beneficiam do status protegido de assalariado em atividades realizadas por empreendedores independentes. (ABDELNOUR; LAMBERT, 20I4) Como observa Gorz, "a pessoa deve se tornar ela mesma uma empresa". (GORZ, 2003, p. 25) As grandes plataformas digitais mercantis desempenham um papel importante nessa precarização. Sua particularidade é exigir mais do que a sim- 
ples disponibilização de uma força de trabalho. Com efeito, elas supõem para aqueles que se comprometem, a dupla disponibilização: de um capital de recursos e de um capital reputacional. Se tomarmos o caso do Uber, os motoristas devem disponibilizar para a plataforma um smartphone, um aplicativo configurado e um carro. O monitoramento realizado pelo aplicativo determinará e construirá o capital reputacional necessário para a continuação da atividade. Isso inaugura, segundo Feher, uma forma de titularização - ou securitização - financeira das relações humanas (FEHER, 20I7), através do estabelecimento de uma relação entre investidores e investidos. A gestão se torna desencarnada. (DUJARIER, 2OI4) Motoristas de Uber não trabalham para a plataforma, eles são investidos pela plataforma. Cabe a eles serem atraentes para o investimento. Diante disso, as proteções habituais caem ou são contornadas. Num contexto em que a uberização do trabalho "é combinada com a hegemonia do capital financeiro, os governos que estão prioritariamente determinados a manter a confiança de seus credores dificilmente serão capazes de incluir a emancipação de todos os trabalhadores em seus cadernos de encargos". (FEHER, 20I7, p. I49)

Postone (2009) observa que, para sair da dominação, é necessário deixar de considerar o trabalho como uma categoria trans-histórica para considerá-lo como uma categoria específica do capitalismo. (HARRIBEY, 2009) Portanto, trata-se de descrevê-lo em sua especificidade e contemporaneidade. É antes de tudo um sistema que mina seus próprios fundamentos. Como no mito grego de Eryschithon, ${ }^{4}$ O capitalismo se autodevora (JAPPE, 2OI7) esgotando as próprias forças nas quais ele se apoia. Constata-se, desse modo, que o sistema engendra o mal-estar para os trabalhadores favorecendo sua autoexploração. Ele reforça a dominação existente, especialmente sua dimensão patriarcal. (JAPPE, 20I7)

O capitalismo promove, assim, a produção - sob o controle de homens -, em detrimento das atividades ditas "reprodutivas" - muitas vezes invisibilizadas - que ocorrem "sobretudo na esfera doméstica e são geralmente

4 Erysichthon é um personagem da mitologia grega cuja fome insaciável o leva a se autodevorar. 
atribuídas às mulheres". (JAPPE, 20I7, p. 234) Assim, o estudo das representações da economia a partir das relações sociais de gênero destaca uma hierarquia que valoriza a produção de mercado em detrimento da reprodução largamente confinada dentro das categorias não mercantis e não monetárias. (LAVILLE, 20I5). Sauvy (1965) ${ }^{5}$ ironizava com o fato de que quando um burguês se casa com sua empregada doméstica, ele reduz o PIB. De fato, a esposa continua a trabalhar na casa, mas não recebe mais salário por esse serviço. Nessa situação, a produção de serviços permanece inalterada antes e depois do casamento, mas a esfera de mercado não a reconhece depois do casamento - já que não tem mais tradução monetária. O trabalho doméstico é, de fato, "apenas uma das expressões típicas de uma vasta economia da sombra, uma economia fantasma, que se desenvolveu em todas as sociedades industriais como complemento, senão fonte da expansão do trabalho remunerado". (GORZ, 2003, p. I05) O desenvolvimento promovido pela economia de mercado implica "o monopólio do trabalho remunerado em relação a todas as outras formas de trabalho" e "uma reorganização do ambiente de modo que o espaço, o tempo, os recursos e os projetos sejam orientados à produção e ao consumo, enquanto que as atividades criadoras de valores de uso, que satisfazem diretamente as necessidades, estagnam ou desaparecem". (GORZ, 2003, p. 107)

Está claro que as "desigualdades de acesso e controle das chamadas esferas produtivas e reprodutivas estão no centro das desigualdades de gênero" e que a marginalização das mulheres "tem sido alimentada pela sua exclusão ou dificuldade em acessar essas formas de riqueza, seja emprego, propriedade ou finanças". (GUERIN; HERSENT; FRAISSE, 20II, p. I5) Para escapar dessa aporia e da invisibilização de atividades essenciais às nossas sociedades, o quadro da economia substantiva de Polanyi parece particularmente adaptado. Incluindo no quadro da análise a reciprocidade, a economia doméstica e a redistribuição, ele participa da emancipação dos atores. Ele permite também

5 Alfred Sauvy é um economista, demógrafo e sociólogo francês falecido em 1990. Ele ficou conhecido pelo seu espírito crítico e sua ousadia ao quebrar ideias prontas. 
pensar na reimbricação do trabalho. Ao concluir esta seção, gostaríamos de dar dois exemplos que testemunham essa capacidade da organização de servir à desconstrução de mercadorias fictícias. O primeiro diz respeito às cooperativas de atividade e de trabalho e o segundo às cooperativas de plataforma.

A primeira Cooperativa de Atividade e de Emprego (CAE) - Coopérative d'activité et d'emploi - nasceu na década de I990, na França. O objetivo inicial desta proposta participava da vontade dos poderes públicos de encorajar os desempregados a criarem seu próprio negócio. A ideia inicial poderia parecer próxima de uma incubadora de empresas. Muito rapidamente, porém, a CAE explorou de maneira pragmática a ideia de mutualização do trabalho, isto é, "de empreendimento coletivo em que as pessoas protegem mutuamente, ao longo do tempo, suas carreiras profissionais". (DELVOLVÉ; VEYER, 2009, p. 2) O princípio de uma CAE consiste em assalariar os membros da cooperativa que são todos empreendedores individuais. Para isso, a CAE assegura a responsabilidade jurídica do coletivo e mutualiza a tesouraria de todos os seus membros. O salário pago pela CAE depende do nível de atividade de cada empreendedor. A força da proposta é que cada empreendedor permanece independente e senhor de suas decisões, desfrutando da proteção de um estatuto de assalariado.

Desde os primeiros contratos comerciais, "todo titular de projeto assina um contrato de trabalho com a CAE por um período indeterminado e se torna um empregado-empreendedor". (SANGIORGIO; VEYER, 2009). Ele está integrado na cooperativa "sem presumir o êxito futuro da (sua) atividade e acompanhado pela estrutura para esclarecer e lançar (seu) projeto". (SANGIORGIO; VEYER, 2009) A presença de um empreendedor no seio de uma CAE pode ser temporária ou de longo prazo. Isso depende de sua escolha pessoal e da evolução de sua atividade. A lógica de uma CAE é distinta de uma organização baseada no assalariamento. De fato, o portador de projeto numa CAE não é colocado numa relação de cliente com prestador de serviços. Em uma CAE, "acompanhantes e acompanhados estão associados ao mesmo projeto". (STERVINOU; NOËL-LEMAITRE, 2008, p. 70) A gestão adotada pela CAE permite geralmente não seguir os exercícios preestabelecidos e impostos, tais como a pesquisa de mercado, as previsões do ne- 
gócios e/ou os critérios prospectivos de rentabilidade econômica. (SANGIORGIO; VEYER, 2009) A relação acompanhante/acompanhado é estabelecida no modo de paridade. O apoio dado ao portador do projeto não é "nem uma assistência e nem aconselhamento de gestão, mas um tipo de escuta benevolente e um acompanhamento entre pares". (SANGIORGIO; VEYER, 2009, p. 55) Além disso, a estrutura coletiva da cooperativa permite "romper o isolamento do portador do projeto e organizar um trabalho de acompanhamento coletivo, por meio de oficinas de intercâmbio de práticas, por exemplo". (SANGIORGIO; VEYER, 2009, p. 55)

As CAEs reivindicam uma abordagem política ao se recusarem a tomar como certo "a atomização da relação de trabalho". (DELVOLVÉ; VEYER, 2009, p. 2) Elas entendem lutar contra os efeitos perversos do desenvolvimento generalizado do autoempreendedorismo, assim como, contra as consequências da "desregulamentação do trabalho tanto quanto da flexibilização das relações econômicas". (DELVOLVÉ; VEYER, 2009, p. 2) Elas fazem isso não apenas assegurando a criação de empresas individuais, mas construindo "uma alternativa à estas, via um projeto de empreendedorismo coletivo". (SANGIORGIO; VEYER, 2009, p. 56) Seu objetivo é reverter o deslocamento da questão social apontada por Feher (2017).

Ao desenvolver a mutualisação dos recursos, qualquer CAE pode constituir uma base financeira suficiente para considerar o desenvolvimento do "seu próprio fundo de investimento, seu próprio fundo de resgate mútuo, seus próprios mecanismos para cobrir perdas operacionais". (SANGIORGIO; VEYER 2009, p. 57) Nesse sentido, observa-se a afirmação de duas dimensões importantes. A primeira é que as CAEs têm vocação para articular as dimensões sociais e profissionais ao reunir atores individuais portadores de projetos empreendedores juntamente com profissionais num mesmo espaço de solidariedade. A exemplo de lugares como os espaços de trabalho conjunto (co-working), hackerspaces ou fablabs, uma CAE como a Coopaname oferece "um espaço físico comum para profissionais de especialidades muito diversas, favorecendo assim encontros e associações inesperadas e, consequentemente, inovação e surgimento de projetos coletivos". (BUREAU, Corsani, 2015, p. 225). A segunda dimensão é que a vontade das CAEs se exprime no quadro 
de uma resposta ampla face aos desafios da proteção social ao oferecer aos cooperados a possibilidade de um estatuto, de uma remuneração salarial, e de uma relação não fundada sobre os mecanismos de uma economia de mercado. Assim, a riqueza das CAEs "transbordam o valor de mercado das atividades que eles abrigam". (BUREAU; CORSANI, 20I5, p. 228) Recusando-se a considerar o trabalho como uma mercadoria, as CAEs têm uma ambição emancipatória em relação aos seus membros e se inscrevem, de fato, na ação pública.

Outro exemplo de gestão substantiva do trabalho pode ser encontrado em cooperativas de plataforma que buscam responder aos novos desafios colocados pelo digital e sua mercadorização. Em seu relatório, Barbezieux e Herody mostram que o grande potencial da economia colaborativa não deve ofuscar a necessidade de reflexão sobre transparência, proteção social, taxação e sustentabilidade das plataformas digitais. (BARBEZIEUX; HERODY, 2OI6) A economia colaborativa gera mudanças significativas que podem colocar em questão o trabalho em sua forma clássica. Novas formas de trabalho aparecem agrupadas sob o termo digital labor. Eles "não têm o gosto, a aparência ou o cheiro de trabalho". (SCHOLZ, 2OI3)

Assim, quando um internauta utiliza um serviço on-line, ele fornece através do gerenciamento de seus dados pessoais um retorno sobre a operação na situação do algoritmo de processamento da plataforma do provedor. Essa atividade pode ser considerada como trabalho não remunerado realizado em proveito da plataforma mercantil, uma vez que a produção de valor é realizada na ausência de uma estrutura contratual. (CASSILLI, 20I5) Os trabalhos sobre o digital labor são múltiplos e se referem tanto à valorização de dados pessoais dos internautas e seu uso, quanto à exploração de conteúdo produzido por amadores, ou à precarização de certas profissões. (BROCA, 20I7) Levando em conta essas reflexões sobre o digital labor e as mudanças induzidas pela transição para uma economia do imaterial (GORZ, 2008), o movimento das cooperativas de plataforma propõem uma alternativa às plataformas de mercado. A ideia por trás desse renascimento cooperativo é a produção de plataformas digitais que sejam nativamente transparentes, democráticas, equitativas e sustentáveis. 
O cooperativismo de plataforma consiste, assim, em articular a experiência histórica do movimento cooperativo com as necessidades sociais do uso da internet. (SCHOLZ, SCHNEIDER, 20I6) Ele se define, então, como a busca por modelos democráticos de propriedade coletiva adaptados à internet e pensados em três tempos. (SCHOLZ, 20I6). Primeiro, trata-se de clonar a tecnologia no coração de plataformas como Uber, Task Rabbit, Airbnb ou UpWork. Em um segundo tempo, trata-se de administrar essa tecnologia em um marco de solidariedade com a propriedade coletiva protegida por organizações não mercantis - sindicatos, cidades, associações, fundações, coletivos de cidadãos. Finalmente, é uma questão de definir princípios de ação para evitar todo tipo de mercantilização. Entre esses, pode-se citar: uma propriedade coletiva; o respeito aos trabalhadores; salários decentes; a transparência dos processos; a portabilidade dos dados; o envolvimento da comunidade de usuários nas decisões; um marco regulatório para definir e proteger os direitos de cada um etc. A força do movimento cooperativo de plataformas é poder abrir sinergias entre os atores da economia solidária e as comunidades associadas ao software livre. (CONATY; BOLLIER, 2OI4)

De acordo com Bauwens e Kostakis (20I7), essa interseção abre cinco tipos de engajamentos portadores de sentido. Em primeiro lugar, as cooperativas abertas se comprometem a recusar a organização da escassez para fins comerciais. Elas reconhecem todas as contribuições oriunda da comunidade, praticando uma contabilidade aberta. Elas se inspiram em modelos de licenciamento público de código aberto para garantir um sistema justo de distribuição e compartilhamento de valor com licenças CopyFair. ${ }^{6}$ Elas adotam ferramentas de design aberto que podem oferecer uma garantia contra as estratégias de obsolescência planejada. Enfim, elas se coordenam mutuamente com sistemas logísticos abertos para promover a economia circular e reduzir a geração de resíduos.

6 As licenças CopyFair se inspiram em licenças de software livre e incentivam a atividade comercial fundada na reciprocidade. A CopyFair requer dos usuários comerciais uma forma comprovada de reciprocidade dentro da comunidade de compartilhamento. Essa contribuição aos comuns é eventualmente financeira. 
As reflexões em torno das cooperativas de plataforma são articuladas com a questão da proteção dos dados sociais. Historicamente, a modernidade é acompanhada por um duplo movimento em que o trabalho deixa a esfera privada para entrar no espaço público e onde o controle social sobre os indivíduos diminui em favor do desenvolvimento de um espaço para a intimidade. (GORZ, 2004) O que observamos nos últimos anos com a hegemonia das plataformas mercantis é a reversão da ordem anterior. A confidencialidade dos dados privados não é mais garantida e a intimidade é cada vez mais exposta no espaço público. Essa perda de privacidade é o resultado de um déficit regulatório por parte dos atores públicos. Assim, como apontam Maurel e Aufrère (2018), é o mercado que regula cada vez mais o uso de dados pessoais. Essa regulação passa por uma negociação contratual e um acordo entre as partes. No entanto, há tanta assimetria entre a plataforma e um indivíduo isolado que a negociação não pode existir na prática. Existe aí um espaço que deve ser regulado por um direito social. Nesse contexto, associações de usuários e coletivos de defesa de direitos têm um papel determinante a desempenhar para que isso aconteça. Para Casili (2013), as associações e coletivos são capazes de criar um modelo de privacidade como negociação (onde) a vida privada deixa de ser um direito individual para se tornar uma negociação coletiva. (CASILI, 20I3) Maurel e Aufrère (2018) sugerem um quadro em três tempos para organizar este modelo e prevenir as derivas. Eles propõem :

- promover ações coletivas - ações de grupo ou class actions - para permitir que os indivíduos façam valer perante os tribunais a defesa de seus direitos individuais contra as plataformas, através de representantes como associações;

- fortalecer a proteção dos usuários nas condições gerais de uso de plataformas sob o modelo de acordos coletivos - para que possam ser objeto de recursos na justiça -;

- passar de uma portabilidade individual para a portabilidade cidadã, ou seja, permitir que os usuários de um serviço on-line recuperem os dados que confiaram a um operador para serem transferidos para um concorrente ou utilizá-los conforme seus próprios propósitos. 
As CAEs, como as cooperativas de plataformas, são formas organizacionais que compartilham a mesma intenção de reintegrar o trabalho, a fim de libertá-lo da lógica do mercado. Essas duas iniciativas mostram que hoje é possível resolidarizar a organização sobre a questão do trabalho. É, no entanto, responsabilidade das políticas públicas se voltarem para a sustentabilidade e proteção dos dados individuais, promoverem tais experiências na luta pela desmercadorizaação do trabalho. Como Gorz recorda "a reviravolta que essa luta vai tomar depende da forma civilizada ou bárbara que a saída do capitalismo tomará". (GORZ, 2008, p. 39)

\section{Moeda social e desmercadorização da moeda}

Como pensar tanto na teoria quanto na prática um movimento de desmercadorização da moeda? Um número cada vez mais crescente de experiências em curso atualmente nos mais diversos países que buscam outras formas de apropriação do dinheiro apontam alguns caminhos. Sob a denominação de moedas sociais, locais ou complementares, tais experiências têm sido objeto de uma série de novos estudos que reforçam outras possibilidades de interpretação da moeda. Essas outras possíveis interpretações entendem a moeda não estritamente em termos econômicos e unicamente como moeda de mercado. (ZELIZER, 2005) De fato, a partir do início do século XX, as discussões sobre a moeda no campo da economia passaram a se concentrar na questão da sua suposta neutralidade. Nesse sentido, a moeda é entendida como um instrumento de troca, incapaz de afetar as relações entre as coisas e as pessoas que participam do conjunto das trocas. Essa ideia de neutralidade monetária se exprime principalmente através da universalização das funções de contar e medir. Entretanto, a sociologia e a antropologia econômica já colocaram amplamente em evidência o caráter inerentemente social e institucional da moeda. (ZELIZER, 2005; LIETAER; KENNEDY, 20IO) A análise de Lietaer e Kennedy (20I0) criticam a neutralidade da moeda a partir de estudo realizado sobre sistemas de trocas com moedas complementares na Alemanha. Esses autores mostram que, no seio desses círculos de intercâmbios, os 
amigos aceitam ser pagos em moeda social por uma ajuda, e até rechaçam o pagamento em moeda oficial nessas ocasiões.

Para a antropologia econômica, a moeda não é única, uniforme e generalizada, mas existe de formas múltiplas. (POLANYI, 2OI2) Diversos estudos mostram a variedade histórica dos tipos, usos e funções da moeda. Em algumas sociedades antigas, o sistema socialmente construído era complexo e contava com uma hierarquia definida entre os diferentes tipos de moedas - moeda para os casamentos, moedas para regulamentar as disputas, entre outras. Em função de sua utilização na vida cotidiana, as moedas adquirem significações diferentes. (ZELIZER, 2005) Sendo assim, não haveria uma moeda abstrata, mas várias moedas relacionadas ao agente que a usa e ao contexto onde se insere. Assim, como criamos a linguagem própria em tal e qual contexto, criamos marcas socialmente coerentes nas moedas. Além disso, a moeda também existe fora do mercado e se submete a diferentes estruturas culturais e sociais. A moeda, vista como um fenômeno de mercado, não dá conta de tratar amplamente o fenômeno, acabando por deixar de lado certas moedas, não fungíveis, não portáveis, subjetivas, e, consequentemente, qualitativamente heterogêneas. (BLANC, I998; ZELIZER, 2005) Em suma, a moeda pode ser singular e não cambiável, e o mais insubstituível dentre os objetos pessoais. (ZELIZER, 2005)

\section{Recuperando a abordagem antropológica da moeda}

Os economistas ortodoxos oferecem uma narrativa muito particular sobre a origem da moeda, que se conta da seguinte maneira: haveria uma idade de ouro - aquela das sociedades primitivas marcadas por um comunismo original - em que todas as riquezas eram repartidas entre os membros e as trocas entre as comunidades eram regidas pelo escambo. No entanto, seu crescimento tornou finalmente necessário a aparição de um meio de troca e a moeda se impôs então como um mecanismo de expressão do valor das coisas e um meio de reserva para trocas futuras..., e é assim que se termina essa história. Para a antropologia, essa história resumida é uma fábula (CAILLÉ, I994), pois carece de respaldo na realidade. (RIGO; FRANÇA FILHO, 2OI7) 
De fato, a antropologia econômica nos evidencia que a moeda tem origem nos sistemas de trocas recíprocas, estabelecidos nas sociedades ancestrais e pré-modernas. Por exemplo, na Grécia antiga, os objetos e seus respectivos valores dependiam enormemente do reconhecimento mútuo entre as pessoas, do tipo de objeto, do status entre pessoas diferentes, formando-se categorias de valores de uso numa estrutura de relações solidárias relativamente complexa. (AGLIETTA; ÓRLEANS, I990) A moeda, então, pode ser vista como um emaranhado de dívidas e créditos na sociedade, os quais a formam e a constroem. A moeda é um "elo que unifica os sistemas de dívida. Ela é uma representação ativa da sociedade como um todo, pois participa desde o início de sua construção". (THÉRET, 2008, p. 3) Sob essa perspectiva, a dimensão simbólica da moeda destaca-se, tendo em vista que o entendimento é o de que ela opera como um símbolo que se relaciona com outros símbolos do sistema, dentro do qual os significados são compartilhados, trocados e fazem sentido.

Numa concepção intermediária entre a exclusivamente simbólica e a exclusivamente econômica, a moeda é entendida como uma forma institucional conectando pessoas e coisas, um sistema de regras que faz com que "a coisa distinta das pessoas" que foi escolhida para representar certas relações entre pessoas, o faça legitimamente. (THÉRET, 2008) Na moeda de mercado, a dívida tornou-se dissociada da pessoa do devedor, devido à expansão das relações mercantis, potencializada pela possibilidade de acumular. Para Aglieta e Órleans (1990), comprar sem ter que pagar imediatamente, bem como ampliar as dívidas transferindo-as a terceiros, provoca uma ampliação no tempo e no espaço, modificando as obrigações monetárias. Um exemplo que ajuda a compreender a concepção antropológica da moeda relaciona-se à poupança funerária. Em meados do século XX, as despesas com o funeral dos entes queridos eram consideravelmente elevadas, mas uma despesa das mais importantes, mesmo para os mais pobres. Era uma questão de honra poder ser enterrado com distinção e, no caso dos ricos, com pompa. Sob a perspectiva da racionalidade econômica, os gastos excessivos com funeral seriam um ato irracional, mas era perfeitamente compreensível do ponto de vista moral. (ZELIZER, 2005) 
As pesquisas etnográficas têm contribuído sobremaneira para o entendimento da moeda e se contrapõem às explicações e interpretações da economia sobre os usos que algumas sociedades antigas fazem de suas moedas. Por exemplo, Rospabé (1995) mostra que os bens preciosos utilizados por essas comunidades como moedas não são usados para comprar bens ou serviços, "mas como símbolos, garantias, contrapartidas, que eles pensam ser primordiais e substanciais à perpetuação da vida”. (ROSPABÉ, 1995, p. 22) Dentre os inúmeros exemplos apontados por Rospabé (1995), o pagamento pela noiva nas sociedades arcaicas é considerado o tipo de pagamento mais comum e talvez mais antigo. $\mathrm{O}$ autor utiliza-se de análises profundas e detalhadas das relações sociais envolvidas nesse tipo de pagamento que se mostram contrárias à tese de "comprar" uma mulher. Em essência, o autor mostra as relações que se formam entre os grupos dos doadores - familiares da mulher - e os grupos dos recebedores - familiares do marido -, relações essas que se caracterizam como uma dívida de vida. O pagamento com a moeda não liberta, ou seja, não dispensa de obrigações futuras, ao contrário, paga-se para manter uma dívida. Assim, "[...] longe de adquirir definitivamente uma mulher e seus filhos, os 'pagadores' da mulher se tornam endividados para com àqueles que são 'doadores' das suas filhas". (ROSPABÉ, I995, p. 4I; RIGO; FRANÇA FILHO, 2OI7)

Se a antropologia da moeda como campo do conhecimento indica a diversidade de usos e funções da moeda em diferentes sociedades e culturas ao longo da história, as diferentes manifestações de uso da moeda hoje reafirmam a necessidade desse olhar ampliado. Entretanto, como entender o atual inventário de tipos e formas de moeda?

\section{Uma pluralidade de moedas: paralela, complementar, local, social}

Para Blanc (1998), as moedas paralelas constituem-se num amplo conjunto de instrumentos monetários. São denominadas "paralelas", porque se justapõem dentro das carteiras dos agentes, coexistindo e complementando a moeda nacional. Tais moedas, denominadas "complementares" por Lietaer e Kennedy (20I0), têm se manifestado em diversos países e sob as mais va- 
riadas formas, inclusive, em países que não passaram por crise financeira ou por algum tipo de recessão econômica, como poderia se pensar. (BLANC, I998; LIETAER; KENNEDY, 20IO) No entanto, alguns casos são notórios, como o caso da Argentina, onde o endividamento das províncias foi o principal motivo para o surgimento de moedas complementares, precisamente a partir de julho de 200I. (COLLIAC, 2005) As moedas paralelas provinciais na Argentina foram amplamente aceitas, inclusive pelo Estado Federal. Dentre elas, a Patacón, moeda paralela em Buenos Aires, era utilizada para pagar dívidas públicas, chegando a $80 \%$ do pagamento das pensões e salários. Além disso, outras instituições, como as bancárias, foram se adequando a essa realidade, passando a aceitar e abrir contas na outra moeda. As influências dos usos dessas moedas foram amplas e complexas, a ponto de, por exemplo, as Lecops, do governo federal, e as Patacones, serem encontradas em outras províncias e não apenas em Buenos Aires, havendo casos, inclusive, em que o número de Patacones era maior do que as moedas da outra província. (COLLIAC, 2005) Assim, há incontáveis exemplos sobre moedas alternativas, cada qual com suas especificidades e surgidas em contextos específicos em resposta a situações também específicas. De modo geral, as manifestações de moedas paralelas, ao contrário do que se possa pensar, não concorrem com a moeda nacional, pois são hierarquicamente inferiores, na medida em que não são utilizadas para certas transações formais como no caso de pagamentos de impostos e taxas. (BLANC, I998; LIETAR; KENNEDY, 20IO)

Vale destacar outro exemplo de moeda complementar que não faz uso, necessariamente, do papel moeda, mas apenas das horas de trabalho dedicadas pelos membros. O sistema mais conhecido é o Time Dollar, experiência encontrada frequentemente nos EUA, e que consiste na troca de serviços - ou horas de serviços - entre vizinhos ou membros de uma rede local. Assim, ao receber uma hora de serviço de alguém, uma hora de serviço é debitada do recebedor e uma hora é creditada para o prestador do serviço e, como uma hora é sempre 60 minutos, não existem juros ou inflação. 
De acordo com Soares (2009, p. 255), "moeda social é uma forma de moeda paralela instituída e administrada por seus próprios usuários, logo, sua emissão é originada na esfera privada da economia". Os sistemas de moedas locais procedentes de coletividades de pessoas com vocação não comercial, apoiados pela lógica da circulação da riqueza e organizados "sobre a base de uma dívida social indefinidamente mantida" (BLANC, 1998, p. 85), a exemplo dos Local Exchange Trading Systems (LETS) nos países anglo-saxônicos e dos Systèmes d'Échanges Locaux (SELs) na França, são denominadas de sociais, comunitárias, solidárias ou mesmo regionais ou locais por Lietaer e Kennedy (20IO, p. 76). No Brasil, são frequentemente chamadas de "moedas sociais" (BÚRIGO, 20IO; MENEZES; CROCCO, 2009; SOARES, 2006, 2009) e, de acordo com França Filho e Silva Júnior (2009), a razão para a denominação "social" diz respeito ao fato delas estarem a serviço das comunidades que as criam e implementam, no intuito de apoiarem na resolução dos seus problemas sociais e econômicos.

\section{Qual relação entre moedas sociais, paralelas, complementares ou locais?}

É precisamente essa dimensão de um controle social ou democrático do dinheiro que tem se constituído no critério mais referido para a definição de moeda social no Brasil e na América Latina de certa forma. Razão pela qual seu uso tem sido invocado em inúmeras experiências de caráter eminentemente associativo ou sem fins lucrativos. Esse caráter social ou democrático não impede sua percepção também enquanto moedas paralelas, na medida em que podem constituir um circuito econômico paralelo ao circuito oficial do dinheiro, conformando uma situação de coexistência num mesmo contexto de sociedade. A coexistência, neste caso, acontece mais na forma de coextensividade, pois não há interação - ou vínculo algum - entre a moeda social vista como moeda paralela e a moeda oficial. Contudo, se as moedas sociais podem ter caráter de moeda paralela, por outro lado, uma grande parte das moedas paralelas não são moedas sociais pelo simples fato de não esta- 
rem baseadas em mecanismos democráticos de controle da sua circulação ou gestão. O caráter complementar da moeda social aparece quando, para além da dimensão de moeda paralela, ela interage com a moeda oficial através de algum mecanismo de convertibilidade. Nesse caso, a moeda social funciona como um circulante local da economia, entretendo relação de paridade com a moeda oficial e sendo passível de câmbio segundo critérios e regras específicas definidas numa relação de acordo social prévio entre atores e instituições num dado contexto territorial. Entretanto, a grande maioria das moedas complementares não são moedas sociais pelo simples fato de não serem emitidas por instituições democráticas ou circularem segundo critérios ou princípios democráticos.

Já o caráter local tem necessariamente acompanhado as práticas de uso de moedas sociais em razão do seu compromisso com a resolução de problemas concretos em contextos territoriais específicos. Ou seja, o caráter local nas moedas sociais é indissociável da natureza democrática do dinheiro. Algumas inovações recentes, como veremos a seguir, ampliam a perspectiva local de uso das moedas sociais através da articulação em rede das iniciativas responsáveis pela gestão da moeda social. Contudo, a capacidade de uma moeda social deixar de ser local acontece apenas na sua versão eletrônica - conforme veremos através do exemplo da plataforma e-dinheiro dos Bancos Comunitários de Desenvolvimento (BCDs) no Brasil. Em resumo, moedas sociais têm caráter cumulativo. Elas são necessariamente paralelas, podem ser complementares em alguns casos e são necessariamente locais, podendo extrapolar a dimensão local na sua versão de moedas sociais eletrônicas em alguns casos.

A Figura 4 a seguir tenta resumir as quatro características das moedas. Esse exercício não se presta à proposição de uma tipologia das moedas já realizadas por uma obra de referência de Blanc (20II). Em particular, Blanc mostrou como os tipos-ideais de moedas comunitárias, complementares e locais se combinam para oferecer uma grande diversidade de formas concretas de moedas sociais. De nossa parte, destacamos a importância do controle democrático na definição das moedas sociais como um elemento distintivo de análise. 
Figura 4 - Panorama dos tipos de moedas paralelas

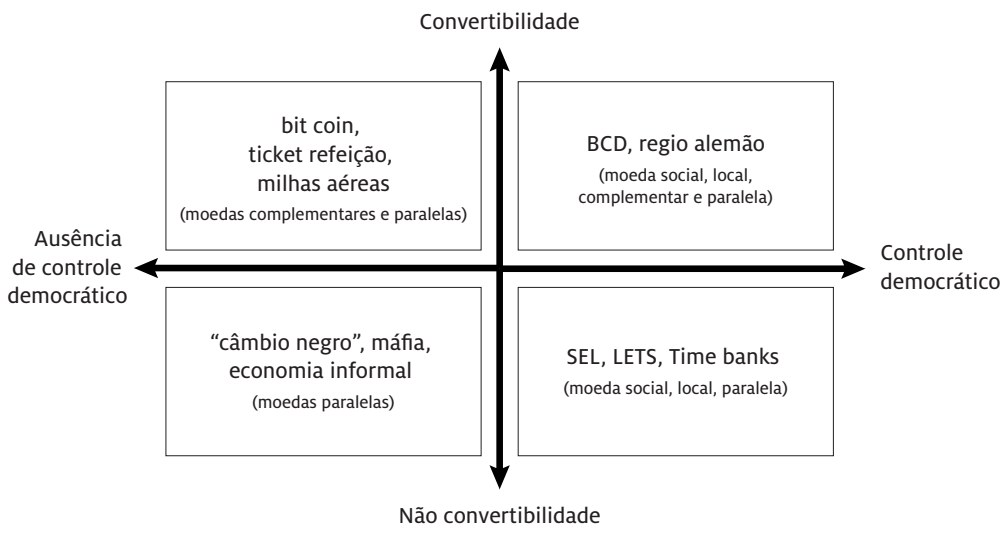

Fonte: adaptado de Eynaud e França Filho (2019).

Quando a conversibilidade é combinada com o controle democrático na gestão da moeda, a moeda social é ao mesmo tempo: local, complementar, paralela. A condição de desmercadorização da moeda social é precisamente a do seu controle democrático. Quando o controle democrático ocorre sem convertibilidade, há um aprofundamento da desmercadorização da moeda, que se afirma mais como moeda social e paralela e menos como moeda complementar ou local. Isso porque, nessas experiências, o local é representado ou substituído pelo grupo. A experiência pode, assim, ganhar em profundidade e, portanto, em autonomia, e perder em extensão, isto é, dificultar a chegada de novos entrantes. Em termos estratégicos, a transformação num caso desse tipo é tão radical que ultrapassa o tempo de uma transição, lenta e gradual, permitindo o aprendizado de quem não dispõe dos mesmos valores socioculturais daqueles que estão no grupo que compartilha a moeda.

\section{Moedas sociais e bancos comunitários de desenvolvimento (BCDs) no Brasil}

Reafirmando a centralidade da dimensão democrática, as moedas sociais podem aparecer de várias formas, como bancos de horas, sistemas de crédito mútuo, moedas complementares ou moedas sociais locais. (PRIMAVERA, 
2003) Geralmente, são criadas moedas sociais para remediar a escassez de dinheiro, distribuir riqueza, gerar conscientização e apoiar as economias populares. É por isso que muitos autores reconhecem que as moedas sociais vão além de um papel econômico e se revelam um instrumento político, social e cultural. (ALBUQUERQUE, 2003; MELO NETO; MAGALHÃES, 2005, MENEZES; CROCCO, 2009; RIGO, 20I4) Ao analisar a moeda social do ponto de vista dos bancos de tempo, Soares (2009) afirma que elas são: "o reflexo de uma busca para colocar a economia a serviço dos objetivos sociais e a reintegração de seus valores à esfera sociocultural. Nessas condições, a moeda social deve ser vista como uma instituição abertamente normativa, associada a pessoas que compartilham os mesmos valores". (SOARES, 2009, p. 255) A autora também argumenta que as moedas sociais são usadas nas práticas de reinvenção da economia. (SOARES, 2009; RIGO; FRANÇA FILHO, 2OI7)

Um dos exemplos mais expressivos de moedas sociais no Brasil tem sido protagonizado nos últimos anos no Brasil através da experiência dos bancos comunitários de desenvolvimento (BCDs), considerada um tipo associativo muito específico de construção das finanças solidárias na prática. (FRANÇA FILHO, 2OI3) Com a moeda social, os BCDs incentivam os moradores a comprar localmente e promover a circulação de dinheiro no local, impedindo a saída da riqueza do território. (RIGO, 20I4; RIGO; FRANÇA FILHO 20I7) Nesse sentido, são vistos como o principal instrumento dos BCDs para promover o desenvolvimento. As moedas sociais favorecem a compra dentro da localidade, valorizam o comércio local e incentivam a criação de novos postos de trabalho na comunidade. (MELO NETO; MAGALHÃES, 2005; MENEZES, CROCCO, 2009; PASSOS, 2008) Com eles, o território se torna um grande clube de trocas cujos benefícios vão além do econômico. Assim, as moedas sociais podem contribuir para a formação de pessoas e o empoderamento das comunidades. (MELO NETO; MAGALHÃES, 2005; PASSOS, 2008)

As principais características das moedas sociais dos BCDs são as seguintes: (a) são concebidas como complemento da moeda nacional sem intenção de substituí-la; b) são fabricadas com componentes de segurança; (c) circulam livremente no comércio local, geralmente oferecendo descontos àqueles que 
os usam; d) podem ser convertidas na moeda oficial somente quando os comerciantes precisam comprar bens fora da comunidade. (MELO NETO; MAGALHÃES, 2006) Podemos acrescentar a isso a falta de juros cobrados por seu uso para desencorajar seu acúmulo e melhorar a circulação. Finalmente, elas se baseiam no controle social. (ALBUQUERQUE 2003, MENEZES; CROCCO, 2009) $\mathrm{O}$ acesso à moeda social é voluntário. É acessado mediante a solicitação de empréstimos diretamente do BCD, recebimento de pagamento em moeda social, troca direta no BCD ou empresa local. (MELO NETO; MAGALHÃES, 2006)

O objetivo dessas moedas sociais é circular o máximo possível no território, pois sua missão é "promover os intercâmbios necessários para a durabilidade e o desenvolvimento de um grupo, comunidade e/ou sociedade". (ALBUQUERQUE, 2009, p. 200) Para que a moeda social circule e promova o desenvolvimento do território, conforme Melo Neto e Magalhães (2006), é necessário que todos os interessados - BCD, comerciantes e residentes ajam de maneira concertada. Para esses autores, o nível de organização de cada BCD, a história da comunidade e o contexto sociopolítico do local são os principais fatores a serem considerados. Um impacto negativo pode ser expresso: a) quando comerciantes ou residentes não querem aceitar a moeda - por medo, ignorância ou simplesmente porque não desejam ingressar no sistema -; (b) quando o BCD não tiver controle sobre a circulação e sobre a quantidade armazenada; c) quando não há incentivos para seu uso. (MELO NETO; MAGALHÃES, 2006)

\section{O enraizamento territorial dos BCDs}

Os BCDs podem ser considerados práticas financeiras solidárias, favorecendo economias populares localizadas em territórios com baixo índice de desenvolvimento humano. (FRANÇA FILHO; SILVA JÚNIOR, 2009) Estruturados a partir da dinâmica associativa local, os BCDs contam com uma série de ferramentas para gerar e aumentar a circulação da riqueza no território. Para esse fim, alguns eixos centrais de ação podem ser articulados em um processo de intervenção: fundo de crédito solidário, moeda local, feiras de produtores locais e formação em economia solidária. Diferentemente das práticas 
tradicionais de microcrédito voltadas para uma organização individual, os BCDs fazem parte de um território, entendido como um bairro popular em uma área urbana, uma comunidade tradicional e/ou rural ou um pequeno município.

Os BCDs buscam investir simultaneamente em capacidade de produção, geração de serviços e consumo territorial. Para isso, financiam e orientam a construção de iniciativas socioprodutivas, a prestação de serviços locais e o consumo local. Além da disseminação de microcréditos com múltiplos propósitos, o objetivo do BCD é construir redes locais da economia solidária, coordenando produtores, prestadores de serviços e consumidores locais. Estes também são chamados de redes de prossumidores ou de prossumatores. (MELO NETO; MAGALHÃES, 2008) Trata-se de associar produtores, consumidores locais e todos os atores do território interessados na instalação de circuitos curtos. Essas redes intentam romper assim a dicotomia clássica da relação entre produção e consumo, característica da lógica convencional de mercado, ao reunir aquilo que foi separado - ofertantes e demandantes. Nesse sentido, tais redes buscam concretizar a expressão de uma outra economia em seu território. Seu objetivo é fortalecer as economias locais e reorganizá-las para promover o desenvolvimento territorial solidário, razão pela qual os BCDs se afirmam como atores de um movimento de economia solidária. Eles fazem isso através de fóruns regionais e nacionais e através da rede brasileira de bancos comunitários. (RIGO; FRANÇA FILHO, 2OI7; FRANÇA FILHO, 2OI3)

A criação de um BCD supõe a expressão de um desejo coletivo e a forte mobilização dos atores do território. Na partida, o BCD deve constituir um capital financeiro básico para seu fundo de crédito, dispor de recursos financeiros suficientes para cobrir seus custos operacionais, formar uma associação e ter pessoas qualificadas para as funções de análise de crédito, aconselhamento, assistência e mediação com a comunidade. Um aspecto importante do funcionamento de um BCD é a segurança fornecida pela existência de um controle baseado em relações de proximidade e confiança mútua. Ao registrar um pedido de crédito, o agente do $\mathrm{BCD}$ pode usar o conhecimento da rede de 
vizinhança para concluir sua análise. Essa mesma rede é uma garantia adicional para o pagamento de créditos. Quatro princípios caracterizam os BCDs: a) a coordenação da iniciativa e a gestão dos recursos são orientados pela comunidade; b) a concessão de microcrédito é guiada pelo desejo de servir a comunidade de maneira justa; c) a gestão dos empréstimos é baseada em relações de proximidade e num controle mais social do que econômico; d) a criação de instrumentos para incentivar o consumo local. Como no exemplo da moeda social, neste último caso, que em geral encontra elevada receptividade entre os produtores, comerciantes e consumidores locais.

\section{Das moedas sociais às moedas sociais eletrônicas}

Atualmente, existem cerca de Ioo BCDs em todo o território brasileiro reunidos na mesma rede nacional. A inovação recente mais importante é a criação de uma moeda social eletrônica. Se as moedas sociais de cada BCD são únicas e válidas localmente, agora elas podem ter uma extensão por meio de uma moeda social eletrônica comum. Isso permite o uso dentro e fora do território local. O uso dos BCDs de uma moeda social eletrônica foi possibilitado pelo desenvolvimento de uma plataforma ou aplicativo independente. Graças a essa plataforma, membros, residentes ou comerciantes podem realizar on-line - internet, telefonia móvel - diferentes tipos de transações financeiras - transferências, compras, pagamentos, recarga de crédito telefônico, solicitação de crédito, extratos etc. Essas funcionalidades permitem uma maior circulação e difusão da moeda social no nível local. A plataforma é gerida pela rede de BCDs em nível nacional. Ela dispõe de estrutura jurídica própria e governança democrática. O desenvolvimento da plataforma foi viabilizado pelo arcabouço legal ( $\mathrm{n}^{\mathrm{O}} \mathrm{I} 2.865 / 2013$ ) estabelecido pelo governo brasileiro para regular a circulação de moedas eletrônicas no país. A principal novidade dessa lei foi permitir que certas instituições que não pertencem ao sistema financeiro - como algumas organizações da sociedade civil dedicadas ao microcrédito - pudessem gerir transações financeiras no limite de até 500 milhões de reais. 
Com a plataforma eletrônica de gestão das moedas sociais, os BCDs abrem um novo horizonte, não apenas para quem faz financiamento solidário, mas também para todos os envolvidos na economia solidária. Isso porque essa experiência favorece um nível de crescimento nunca antes imaginado. De fato, esse sistema permite que os recursos da economia de mercado sejam redirecionados para a economia solidária por simples operações on-line dos usuários. Essa é uma oportunidade para o BCD construir patrimônio significativo e ter poder de reinvestimento nos territórios. Esse horizonte de possibilidade não deixa de ter grandes desafios. Em primeiro lugar, a plataforma da rede nacional de BCDs deve enfrentar a concorrência dos principais players financeiros, mas também de uma infinidade de pequenos players FinTech. Eles veem o campo das moedas eletrônicas como um novo mercado e fazem inúmeras ofertas de serviços, especialmente, ofertas disponíveis pelo celular.

Resta ao BCD a força de seu projeto político baseado em outra economia. Isso pressupõe a participação ativa dos habitantes em cada território pertencente aos BCDs. São justamente os próprios moradores, enquanto parceiros e usuários da plataforma, que constituem a força da rede nacional. A estratégia do BCD visa então fortalecer sua inclusão em uma economia solidária, atendendo aos requisitos legais do seu campo de atividade. É, acima de tudo, um desafio de legitimidade para as práticas de finanças solidárias.

\section{Incubação solidária e desmercadorização da natureza}

Observamos no tópico anterior, através do exemplo de uso das moedas sociais com os BCDs no Brasil, que o propósito da iniciativa extrapola seu nível apenas organizacional. As práticas dos BCDs apenas fazem sentido quando favorecem processos de articulação entre atores e instituições num dado contexto. Enquanto dispositivo, os BCDs se destacam nessa estratégia de construção de redes para o desenvolvimento local pela sua própria natureza nucleadora, isto é, sua capacidade em mobilizar tanto os sujeitos individuais quanto os estabelecimentos e instituições do lugar. Os instrumentos utilizados pelos BCDs constituem os meios para favorecer sua vocação articuladora, sendo a moeda social um elemento privilegiado. 
Se o território representa a terra onde habitam as pessoas, e a terra, por sua vez, simboliza a própria natureza ou ecossistema de vida dos sujeitos, então, pensar uma ação mais ampla de reapropriação do território pelos próprios sujeitos que nele habitam pode ser visto como um processo de desmercadorização da natureza. O exemplo dos BCDs e a plataforma mais ampla de fortalecimento de práticas de economia solidária em rede nos territórios aponta precisamente nessa direção. De todo modo, experiências desse tipo não podem ser compreendidas sem outras estruturas e instâncias de apoio institucionais dela participando. No Brasil, inúmeras experiências importantes a esse respeito acontecem através do papel relevante desempenhado por certas organizações da sociedade civil, por algumas instâncias governamentais desenvolvendo projetos inovadores ou ainda através de inúmeras universidades realizando uma prática emblemática de colaboração designada como incubação tecnológica de economia solidária.

As incubadoras de economia solidária se distinguem substancialmente das práticas mais conhecidas de incubação de empresas privadas. Estas, aparecem no Brasil no início dos anos I980 vinculados a centros de pesquisas e parques tecnológicos num contexto de descentralização das políticas de Ciência, Tecnologia e Inovação (CT\&I). (HIGUCHI; MACHADO; TEIXEIRA, 2006) Segundo definição da Associação Nacional de Entidades Promotoras de Empreendimentos Inovadores (Anprotec), as incubadoras são espaços criados para abrigar empresas e dotados de estrutura para favorecer a transferência de resultados de pesquisa para atividades produtivas. Com esse intuito, a expectativa é de que a empresa, de base tecnológica ou tradicional - dependendo da incubadora -, encontre condições para enfrentar a realidade de mercado contando com seus próprios recursos em termos de instalação física. (ANPROTEC, 2008) Com isso, existem casos em que essas incubadoras abrigam fisicamente tais empresas em fase inicial e prestam o serviço de assessoria mediante uma taxa subsidiada. (FRANÇA FILHO; CUNHA, 2OIO)

Por sua vez, a incubação no campo da economia solidária é muito recente e se desenvolve num propósito muito diferente. Mais conhecida sob a 
rubrica de Incubadoras Tecnológicas de Cooperativas Populares (ITCPs), essas experiências se caracterizaram pelo apoio prestado às iniciativas de organização popular, sobretudo na forma de cooperativas e associações, criadas numa estratégia de enfrentamento do desemprego. A primeira experiência aconteceu em 1995 na UFRJ, no interior do seu Instituto Alberto Luiz Coimbra de Pós-Graduação e Pesquisa de Engenharia (Coppe). Na década seguinte, ocorre um crescimento expressivo do número dessas incubadoras num contexto político institucional mais favorável ao apoio à economia solidária no Brasil. Posteriormente, foram criadas mais de uma centena de tais incubadoras estruturadas em duas redes nacionais. A origem desse tipo de experiência parece ter inaugurado no âmbito da universidade brasileira uma preocupação em dirigir o desenvolvimento da pesquisa tecnológica para o trabalho ou a sociedade, invertendo uma lógica convencional de investimento direcionado ao mercado. Esse trabalho de incubação em economia solidária parece refletir, ainda, um novo momento da história do trabalho de assessoria à organização popular no Brasil, que esteve fortemente ligado a algumas ONGs e instituições vinculadas a setores progressistas da Igreja. Em certa medida, a incubação em economia solidária reatualiza e ressignifica um certo número de práticas de assessoria aos movimentos sociais. Em especial, fortalece o apoio técnico em gestão que antes era praticamente ausente dos processos de formação política. (FRANÇA FILHO; CUNHA, 2OIO)

\section{Diferenças fundamentais: do objeto ao método de incubação}

Em termos operacionais, quatro diferenças marcam a incubação de economia solidária em relação àquela das empresas. Em primeiro lugar, está voltada para um público de baixa renda que se organiza, na maior parte dos casos, em pequenas cooperativas. Segundo, nesse processo, normalmente, não incidem taxas como um componente importante dos subsídios sobre os empreendimentos incubados. Em terceiro lugar, as iniciativas incubadas também não são abrigadas pelas instalações das incubadoras, a exceção de alguns 
casos de incubadoras públicas. Uma quarta diferença é o recorte, que faz com que a incubação em economia solidária lide, principalmente, com empreendimentos solidários, de preferência no formato de cooperativas, incitando a constituição de processos de autogestão nos empreendimentos criados. Essas quatro diferenças podem ser resumidas em duas, concernindo o objeto da incubação e o seu método. De fato, o público prioritário dos processos de incubação com economia solidária, bem como o ambiente onde tais práticas ocorrem como os territórios caracterizados pelo alto grau de exclusão socioeconômica não são vistos pelas agências de fomento como ambientes propícios à inovação, mas devendo fazer objeto de ações sociais reparadoras. (FRANÇA FILHO; CUNHA, 2OIO)

Do ponto de vista do objeto da incubação, os Empreendimentos Econômicos Solidários (EESs) são, na maioria dos casos, constituídos por pessoas de baixa renda, com escolaridade incompleta e, por isso, detentoras de baixa qualificação para o mercado de trabalho. Enquanto perfil geral, esse é um público constituído de pessoas que se envolvem em diferentes atividades, na maioria das vezes informais, como estratégia de manutenção dos parcos recursos necessários à sua sobrevivência. Por isso, podemos caracterizar sua inserção ocupacional como pluriativa, embora marcada pela precariedade. A exceção diz respeito ao público dos EES de maior porte que existem em quantidade muito menor, porém, com uma absorção muito maior de trabalhadores. Estes, apresentam-se como grandes cooperativas, constituídas por trabalhadores mais qualificados do ponto de vista sócio-ocupacional e que são, em geral, detentores de formação técnica, sobretudo em nível médio. De qualquer sorte, para a maioria dos casos, trata-se de um público bastante vulnerável do ponto de vista socioeconômico e sócio-ocupacional, excluído das políticas de investimento produtivo, não deixando, entretanto, de constituir parte da População Economicamente Ativa (PEA). Já os seus territórios de pertencimento costumam ser definidos como zonas de exclusão pela baixa propensão do investimento público: comunidades e outras zonas rurais; comunidades tradicionais - ribeirinhos, quilombolas, pescadores e marisqueiras, entre outras -; favelas e ou bairros periféricos em grandes centros urbanos. 
Já do ponto de vista do método, a incubação em economia solidária rompe de maneira radical com os princípios característicos das práticas convencionais de incubação de empresas marcadas pelo paradigma difusionista em termos de abordagem de CT\&I. Esse paradigma se fundamenta na transferência tecnológica apoiada na hierarquização e especialização do conhecimento. Já na incubação em economia solidária, as soluções tecnológicas geradas são sempre definidas a partir do seu caráter socialmente apropriado à realidade das iniciativas e seus respectivos contextos. É assim que no lugar de transferência tecnológica, se afirma uma lógica de coconstrução de soluções tecnológicas na qual tanto os saberes acadêmicos quanto os populares são valorizados. O intuito é de favorecer processos de emancipação das pessoas, grupos e seus respectivos territórios. Por isso, o protagonismo não pode estar na universidade, e sim no próprio local e/ou na sua relação de interação com a universidade. Logo, uma ecologia de saberes é mobilizada enquanto fonte de conhecimento: das diferentes fontes de conhecimento presentes na diversidade que constitui a cultura popular, passando pelos aportes oriundos das áreas mais duras da ciência como as engenharias, até as diferentes contribuições no campo das chamadas humanidades. E nestas se destacam variados aportes em termos de teorias da educação, com especial relevância para os métodos de educação popular e as abordagens freirianas, como na ênfase sobre o papel da dialogicidade na aprendizagem e construção coletiva do conhecimento. (FRANÇA FILHO; CUNHA, 2OIO)

\section{Da incubação de iniciativas à incubação de territórios}

Se esses princípios da incubação em economia solidária têm se mantido e se fortalecido nos últimos tempos, a sua estratégia principal, por outro lado, tem sido repensada. Da ênfase sobre o fortalecimento das cooperativas populares enquanto empreendimentos autogeridos, a preocupação se deslocou para o ambiente, contexto e território onde se situam. Uma incubação de empreendimento individual se revela tarefa inglória diante das próprias dificuldades em sobreviver isoladamente. Cresce, então, as preocupações com a 
incubação do próprio território, e com ela, os próprios meios ou dispositivos mobilizados para tanto.

Do ponto de vista da incubação tecnológica, a incorporação de um horizonte de desenvolvimento territorial relacionado à economia solidária pressupõe uma mudança no objeto da incubação: da organização ou empreendimento para o território. Esse deslocamento do objeto da incubação não indica uma oposição entre ambos. A perspectiva da incubação territorial tenta ir além da incubação de empreendimentos. Isso quer dizer que esta última passa a ser parte da primeira. Ou seja, permanece de grande relevância o trabalho de assessoria técnica aos empreendimentos. Entretanto, uma nova ênfase se coloca na prática da incubação: de uma preocupação socioeconômica para um enfoque mais sociopolítico, ou, de uma perspectiva socioprodutiva para uma perspectiva sócio-organizativa. Entende-se por enfoque sociopolítico ou perspectiva sócio-organizativa o importante trabalho de fortalecimento da capacidade de auto-organização local, que envolve dois níveis de abordagem. O primeiro é aquele voltado para dentro do próprio local, através do fomento aos diferentes mecanismos de ação pública. Já o segundo, é aquele que projeta a relação do local para fora dele, através da ênfase nos processos de articulação institucional, que envolve os diferentes tipos de acordos e relações com instâncias e entidades supralocais. Nesse enfoque sociopolítico, portanto, enfatiza-se o processo de mobilização local para discussão pública dos problemas comuns vividos pelas pessoas no seu contexto territorial. A ideia é de fortalecer os espaços públicos no território que favoreçam o exercício de uma prática política de discussão pública dos seus assuntos comuns. (FRANÇA FILHO; CUNHA, 20IO) As associações tornam-se iniciativas de alta importância nesse sentido, por isso, uma das tarefas elementares na incubação é justamente trabalhar no apoio as associações locais, enquanto espaços públicos de proximidade. (LAVILLE, 1994)

O estímulo à dinâmica associativa no local tem o intuito de criar as condições para catapultar o desenvolvimento de um lugar, segundo a premissa de que, primeiro uma comunidade precisa estar organizada, para assim, encaminhar o 
seu processo de desenvolvimento de forma sustentável. Afinal de contas, é ela que deve decidir os rumos do seu desenvolvimento. Assim, o conceito servindo como diretriz para uma lógica de desenvolvimento que prioriza o território é justamente o de rede local de economia solidária. Uma rede local de economia solidária pode ser compreendida como uma associação ou articulação de vários empreendimentos e/ou iniciativas de economia solidária, além das demais iniciativas existentes no local, com vistas a constituição de um circuito próprio de relações socioeconômicas e intercâmbio de experiências e saberes formativos. São dois os principais objetivos de uma rede de tal natureza: permitir a sustentabilidade dos empreendimentos e/ou iniciativas de economia solidária em particular; e fortalecer o potencial endógeno de um território quanto à capacidade de promoção do seu próprio processo de desenvolvimento. (FRANÇA FILHO; CUNHA, 2OIO; MANCE, 2003)

Em termos tipológicos, as formas de manifestação de uma rede de economia solidária podem se dar de três maneiras: transterritorialmente, territorialmente e mista. (FRANÇA FILHO; CUNHA, 2OIO) No nível transterritorial, uma rede desse tipo pode envolver uma articulação de vários empreendimentos atuando na cadeia produtiva de determinado produto. Tal rede pode envolver, também, acordos e contratos bilaterais - ou multilaterais - entre iniciativas ou organizações em diferentes áreas ou níveis de atuação, a exemplo do comércio justo. Além disso, esse tipo de rede pode envolver, ainda, empreendimentos de um mesmo tipo que compartilham princípios, saberes e um modo de funcionamento próprio, muito embora preservem sua autonomia enquanto organização individual, fruto do seu contexto particular. No nível territorial, uma rede de economia solidária envolve, numa mesma base territorial, a articulação de empreendimentos e/ou iniciativas de economia solidária em diferentes âmbitos de atuação: consumo ético, finanças solidárias, tecnologias livres, comércio justo, produção autogestionária e serviços locais, entre outros. Nesse sentido, esse tipo de rede supõe articulação entre iniciativas de distintas naturezas: socioeconômicas, sociopolíticas, socioculturais e socioambientais. Além disso, ela admite diferentes níveis de articulação com 
a economia local preexistente ou já estabelecida. Finalmente, o terceiro tipo é aqui denominado de misto, pois supõe uma dimensão terrritorial, porém, envolvendo parcerias e articulações transterritoriais. Na prática, as redes locais de economia solidária tendem ao caráter misto, sendo raro encontrar alguma experiência limitada a um âmbito geográfico específico, devido à sustentabilidade da própria rede, que tende a conectar-se com outras redes no processo de expansão de suas atividades. (MANCE, 2000, 2002) O próprio de tais redes, aliás, é de extrapolar sua dimensão territorial. Contudo, em se tratando de economia solidária, considera-se por princípio que tal extrapolação tende a acontecer somente a partir de raízes muito sólidas fincadas localmente, ou seja, do fortalecimento da economia local. (2002; DAWBOR, 2007; FRANÇA FILHO, CUNHA, 2OIO; MANCE, 2000)

Assim, as redes de economia solidária podem ser vistas como uma estratégia complexa de cooperação para o desenvolvimento local. (FRANÇA FILHO; CUNHA, 20IO) Ao induzir à constituição de circuitos próprios de comercialização e produção, tais redes criam uma nova modalidade de regulação socioeconômica, o que supõe uma outra forma de funcionamento da economia. Nesta, a competição como princípio regulador da relação entre os agentes, perde sentido, pois a construção da oferta é articulada de acordo com as demandas previamente colocadas num determinado contexto territorial. (FRANÇA FILHO, 2007; LAVILLE, 1994) Desse modo, os contratos e acordos são estabelecidos com base em princípios, valores e regras que vão muito além dos imperativos de rentabilidade econômica da atividade: são levados em consideração critérios de cidadania em termos de acesso a direitos, redistribuição equitativa dos benefícios, remuneração digna, efeitos ambientais e compromisso com o contexto local de desenvolvimento das atividades, entre outros, a exemplo das práticas de comércio justo, consumo ético e consciente e educação ambiental. Importa salientar o potencial contido nessa nova forma de fazer economia na direção da institucionalização de novos padrões de relação com os poderes públicos, em termos de compras governamentais e contratos negociados. 
Com a ideia de uma outra economia, a partir de redes de economia solidária, está-se pensando em novas formas de articulação institucionais envolvendo empreendimentos de economia solidária e instituições públicas governamentais ou não governamentais. Do ponto de vista de uma lógica de desenvolvimento (SACHS, 2006; DAWBOR, 2007), a aposta em redes de economia solidária rompe de maneira contundente com as soluções mais conhecidas e predominantes em termos de combate à falta de trabalho, as quais giram em torno do que pode-se denominar de concepção insercional-competitiva, em oposição à concepção sustentável-solidária. (FRANÇA FILHO, 2008) As redes locais de economia solidária podem ser vislumbradas também como a tradução concreta da ideia de uma outra economia acontecendo na prática. Isso porque, se numa lógica de economia convencional, de mercado, ofertantes e demandantes constituem agentes independentes, e é através da competição entorno do preço dos bens e serviços que estes interesses supostamente harmonizar-se-iam, por outro lado, numa lógica de redes locais de economia solidária, as ofertas são decididas no seio dos espaços públicos a partir de demandas genuinamente identificadas pelos próprios cidadãos. Ou seja, acontece um processo de construção conjunta da oferta e da demanda que qualifica de forma significativa a prática empreendedora.

Diferentemente de uma lógica de empreendedorismo vulgar, em que negócios são criados a partir do "faro" individual das pessoas, sem uma preocupação maior sobre o impacto da atividade no seu contexto, na perspectiva da economia solidária, a proposição de empreendimentos primeiro é fruto de um efetivo diagnóstico local sobre sua necessidade e, segundo, deve se pautar por princípios éticos de uma ação associada. Assim, na lógica de redes locais de economia solidária, a construção conjunta da oferta e da demanda pode ser vista também como uma prática de produção e consumo associadas, que também ocorre entre usuários e prestadores de serviços. Os empreendimentos são geridos por moradores que prestam serviços aos próprios moradores. Também se observa nesta outra economia fomentada pelas redes locais de economia solidária, um claro enraizamento do aspecto econômico da ativida- 
de numa esfera política. Isto é, a elaboração das atividades socioeconômicas é decidida numa dinâmica local de ação pública, quando moradores reunidos no seio dos seus espaços associativos decidem sobre os empreendimentos a serem constituídos, qualificando então a própria ação empreendedora. Nesse sentido, tais práticas parecem estimular o aprendizado - pelo exercício cotidiano - de uma cultura política democrática, contrastando fortemente com a tradição clientelista que ainda revela-se bastante influente no universo das associações de moradores.

Por outro lado, é importante ressaltar que as redes locais de economia solidária não são redes exclusivamente econômicas, já que elas reúnem tanto iniciativas socioprodutivas quanto iniciativas sócio-organizativas. A rede pode ser vista inclusive como o mapa no qual a comunidade orienta o seu próprio processo de desenvolvimento. Enquanto um mapa, cabe salientar o papel diferenciado de práticas de finanças solidárias, a exemplo dos BCDs, numa rede local de economia solidária. Tais iniciativas parecem cumprir claramente um duplo papel. De um lado, os BCDs têm potencial de forte contribuição para o que poderíamos chamar de endogeneização da renda localmente. Pelo fato de ser uma fonte de geração de recursos e estimular a circulação da renda localmente. Isso é possível graças aos diferentes mecanismos de gestão de um BCD: linhas de microcréditos adaptadas as necessidades locais; tecnologias de concessão do microcrédito baseada em relações de proximidade; e uso de moedas sociais como circulantes locais na economia. (FRANÇA FILHO, 20I3) Por outro lado, o sistema de microcrédito local solidário que incita um BCD pressupõe uma série de regras sociais de tipo novo, em que moradores são induzidos à uma efetiva participação política na direção da construção de pactos sociais no território. É assim, por exemplo, quando comerciantes, num bairro popular ou comunidade tradicional, participam das reuniões nos fóruns associativos locais que tratam das regras de circulação da moeda social e assinam os acordos e contratos sobre a aceitação de tais moedas. Ou ainda, quando moradores optam por uma relação de confiança entre eles para viabilizar o sistema de microcrédito local orientado pelo BCD. 


\section{Um caso emblemático na Bahia}

Matarandiba é um pequeno vilarejo de marisqueiras e pescadores, situado na contra costa da Ilha de Itaparica que fica no outro lado da grande baía recortando boa parte da costa da cidade de Salvador, no nordeste do Brasil. A ilha de Itaparica compreende dois municípios com baixos indicadores econômico-sociais. Matarandiba, com pouco menos de mil habitantes, fica distante quase $40 \mathrm{~km}$ da sede do município de Vera Cruz, sendo pouco assistida do ponto de vista de políticas públicas. Num esforço de contrapor a carência de recursos localmente, seus moradores empreendem esforços de auto-organização associativa numa perspectiva de desenvolvimento local-comunitário. Através de parceria com uma organização industrial instalada na região e com a incubadora de economia solidária da Universidade Federal da Bahia (UFBA), além de outras parcerias institucionais, iniciam uma série de atividades objetivando uma maior apropriação do seu território pelos próprios moradores. Iniciativas em rede são então constituídas pouco a pouco e vão conformando a "rede Matarandiba de cultura e economia solidária" enquanto estratégia de desenvolvimento comunitário.

A diversidade dos empreendimentos criados e suas distintas naturezas - socioprodutivo e sócio-organizativo, socioeconômico e sociopolítico, sociocultural e socioambiental - indicam o perfil e abrangência da rede. Duas associações foram formalmente constituídas e são responsáveis pela coordenação de múltiplas e diferenciadas iniciativas locais. A Associação Comunitária de Matarandiba (Ascoma) apoia empreendimentos como o banco comunitário Ilhamar, que faz a gestão da moeda social concha e de uma série de outros serviços de finanças solidárias. Além do BCD Ilhamar, a Ascoma apoia também uma rádio comunitária, uma iniciativa de cinema comunitário, um infocentro comunitário, uma atividade de cultivo e produção agroecológica de alimentos, uma iniciativa de maricultura familiar e artesanal baseada em ostreicultura, uma padaria comunitária, a gestão do transporte público local e uma iniciativa de turismo de base comunitária. 
Já a Associação Cultural de Matarandiba (Ascomat) realiza um intenso trabalho de gestão da cultura local através de diferentes iniciativas de resgate e preservação de um acervo variado de manifestações de cultura popular tradicional. São algumas atividades realizadas pela Ascomat: fortalecimento dos grupos culturais locais - de dança e de música -, bem como, das manifestações e festejos locais; gestão de um importante equipamento cultural compreendendo um ponto de cultura e de memória, ou seja, espaço de leitura, reforço escolar e museu da comunidade; além de promoção de uma série de outras atividades como gravação de CDs e realização de apresentações culturais. A participação em editais públicos através de proposição de projetos culturais tem sido uma das principais estratégias de atuação da Ascomat. Com esse amplo e variado leque de inciativas locais, a "rede Matarandiba de cultura e economia solidária" intenta simultaneamente: o fortalecimento da sua economia local; a preservação do seu habitat natural e ecossistema de vida; o fortalecimento da capacidade de auto-organização política na discussão e deliberação coletiva sobre seus problemas comuns; e a preservação e fortalecimento da sua própria memória local em termos de sua identidade, de sua história, enfim, daquilo que constitui sua cultura. O intento é ousado, diante da simplicidade e humildade dos seus moradores e do seu caráter intergeracional, mas se constrói na prática a cada dia, com diferentes movimentos e oscilações, próprias de uma dinâmica social que não acontece sem desafios.

Práticas de incubação em economia solidária, ao passo que apontam diretamente um outro modo de apropriação do território pelos seus próprios sujeitos, indicando uma desmercadorização da natureza, também podem compreender a desmercadorização do trabalho e da moeda ao ressignificar o trabalho no sentido que se lhes atribui as atividades empreendidas coletivamente e propor outra forma de relação com o dinheiro, através do uso de moedas sociais. Essas práticas de dermercadorização das mercadorias fictícias - natureza, moeda e trabalho - constituem as respostas encontradas pelas populações locais para o atendimento de suas necessidades. Enquanto tais, elas representam soluções inovadoras para os problemas localmente colocados. Contudo, o caráter tão diferenciado de tais práticas conjugado com seu propó- 
sito substantivo nos conduz a pensar sobre a natureza da inovação que nelas se verifica. Se não se trata de inovação tecnológica em sentido convencional, estaríamos diante de novas formas de inovação social? Se sim, é possível a avançar a hipótese segundo a qual o processo de desmercadorização de mercadorias fictícias, enquanto desafio de gestão, consiste necessariamente numa forma de inovação social.

\section{RE-SOLIDARIZAR AS ORGANIZAÇÕES ATRAVÉS DA INOVAÇÃO SOCIAL}

As práticas de dermercadorização do trabalho, da natureza e da moeda são as soluções encontradas em diferentes lugares do planeta e são fruto de ações coletivas de cidadãos que se engajam na gestão dos seus próprios recursos. Elas fazem apelo a uma outra economia diante dos limites da própria racionalidade de mercado em responder ao intento pretendido. Se uma outra gestão constitui o modo de operacionalizar tais práticas de dermercadorização, então é preciso reconhecer essa outra gestão como um lócus fundamental de inovação, pelas próprias soluções apresentadas. A questão fundamental então é como definir a natureza da inovação em processos de dermercadorização da natureza, do trabalho ou da moeda? Nesse intuito, nosso argumento consiste primeiro em tentar mostrar por que a forma convencional de inovação, consubstanciado na noção de inovação tecnológica, não consegue apreender o tipo de prática aqui descrita. Em segundo lugar, iremos salientar como as características apresentadas em tais experiências nos ajudam a redefinir o próprio conceito de inovação.

\section{Inovação tecnológica e inovação social: genealogia de um conceito}

Se existe inovação nas práticas de incubação em economia solidária, importa compreender a natureza dessa inovação. Enquanto temática, a inovação não se apresenta de maneira uniforme, trata-se de um conceito que se sujeita a diferentes interpretações. Nas sociedades ocidentais, a inovação é, muitas vezes, invocada como um elemento fundamental de uma possível saída da cri- 
se. Centrado nas empresas, essa abordagem da inovação coloca ênfase sobre a mudança na organização do trabalho, sobre a melhoria de procedimentos técnicos, sobre os ganhos de produtividade ligados às novas tecnologias e sobre a invenção de serviços e produtos novos. (KLEIN; LAVILLE; MOULAERT, 2OI4)

Nessa perspectiva, geralmente se distingue a inovação de processo da inovação de produtos. A primeira, concerne a implementação ou a adoção de novos métodos de produção ou de distribuição. Tais mudanças pode afetar separadamente ou simultaneamente - os materiais, os recursos humanos ou os métodos de trabalho. (OCDE, 1997) A segunda, consiste no desdobramento ou na venda de um melhor produto performativo a fim de fornecer aos consumadores um serviço novo ou melhorado. (OCDE, 1997) Em todo o caso, a compreensão da inovação está focalizada no campo da engenharia, da indústria e das ciências naturais. A ideia implícita comum ao conjunto dessas definições é a seguinte: a inovação é uma questão de especialistas e de técnicos. Nesse sentido, a inovação apenas se resolveria através de investimentos em Pesquisa e Desenvolvimento (P\&D). Esse tipo de inovação, a dominante tecnológica, se beneficia de um suporte institucional importante. Ela impressiona os responsáveis políticos pela possibilidade de certificação e de uma difusão rápida junto ao público. (FRANÇA FILHO, 20I8)

Geralmente, o pensamento da inovação se opõe a uma visão determinista de evolução da sociedade, ou seja, a uma visão em que o progresso e a modernização das práticas sociais são caracterizados por uma forma de reversibilidade. (KLEIN; LAVILLE; MOULAERT, 20I4) O primeiro autor importante que se interessou pela inovação foi Schumpeter. Na sua obra clássica, Teoria do desenvolvimento econômico, publicada em I9II, ele analisa as causas do processo do desenvolvimento. Ele enfatiza dois fatores-chave que interagem: a inovação e o empreendedorismo. A inovação é compreendida como um elemento disruptivo que gera uma perturbação do equilíbrio e/ou uma ruptura da ordem estabelecida. Nesse sentido, ela produz mudanças que têm uma dimensão material ou no plano dos valores. A visão de Schumpeter é pragmática: a atividade econômica é guiada pelos que tomam decisões, ou seja, os empreendedores. Se esses são raramente inventores, eles são por outro lado passadores. Os empreendedores 
são os atores da mudança, pois eles estão em condições de produzir e de difundir as inovações. É nisso que a teoria de Schumpeter se diferencia fundamentalmente das perspectivas deterministas e macrossociais. Ele faz da inovação uma resposta criativa a três grandes categorias de obstáculos: a incerteza ligada ao risco, a dificuldade de criar e a resistência do meio. (SCHUMPETER, 1935) Schumpeter mostra que não é suficiente produzir um sabão satisfatório, é preciso também ensinar as pessoas a se lavarem. (KLEIN; LAVILLE; MOULAERT, 20I4) Isso conduz a distinguir a invenção da inovação. Ele coloca, assim, que a inovação é o resultado da difusão e da apropriação de uma invenção. Dito de outro modo, a inovação é uma invenção exitosa.

O trabalho pioneiro de Schumpeter permitiu lançar as bases de uma reflexão sobre a inovação. Sua análise permanece, contudo, limitada ao espaço da mudança técnica e ao perímetro da empresa. A perspectiva aberta por Schumpeter é completada por Perroux (I993). Este autor associa a inovação ao que ele designa como "polo de crescimento". Ele afirma que a inovação não surge nem em todos os lugares nem simultaneamente. Ela segue uma trajetória complexa pois sua difusão está ligada a um processo de adoção gradual. Para Perroux, a inovação é importante pois ela engendra o crescimento e a mudança cultural e permite a modernização das estruturas produtivas. Será necessário esperar os anos 80 para vermos aparecer uma reflexão diferente sobre inovação, distinguindo a ideia de inovação social dos segmentos econômicos e da ênfase nas tecnologias, para tentar mostrar que, mesmo se todas as inovações têm uma dimensão social, a inovação como tal tem especificidades. (FRANÇA FILHO, 20I8)

\section{Uma inflexão necessária: a inovação compreendida como inovação social}

A emergência do conceito de inovação social ocorre justamente em função da necessidade de um olhar da parte de pesquisadores e profissionais sobre outras dimensões do fenômeno da inovação, para além da econômica e da tecnológica. A ascensão do conceito guarda relação com um contexto de 
maior complexificação dos problemas socioambientais, exigindo novas e mais criativas respostas dos diversos setores da sociedade. A inovação, redefinida, passa a ser um tema central na agenda de debate. Embora não constituído como uma área de pesquisa científica, importantes estudos sobre o tema foram desenvolvidos nos últimos anos em diferentes centros de pesquisa, com destaque para o trabalho pioneiro do Centre de Recherche sur les Innovations Sociales (Crises) na Universidade de Québec, no Canadá. No bojo das pesquisas do Crises, delineiam-se algumas definições mais conhecidas para a inovação social. Em Bouchard, por exemplo, entende-se por inovação social "toda nova abordagem, nova prática ou nova intervenção, ou ainda todo novo produto constituído para melhorar uma situação ou solucionar um problema social tendo encontrado destinação, seja no nível de instituições, de organizações ou de comunidades". (BOUCHARD, 1999) Dito de outro modo, inovação social pode ser definida como "uma experimentação social exitosa e replicável”. (CHAMBON; DAVID; DEVEREY, 1982) Nessa forma de argumentar, se a inovação social deve comprovar sua utilidade social, sua validação pode até passar pelo mercado, mas acima de tudo pela sua institucionalização através dos serviços públicos oriundos do estado ou dos diferentes mecanismos da própria sociedade.

As inovações sociais podem se apresentar, então, como inovações organizacionais - o que é mais comum - ou como inovações institucionais - o que é menos frequente -, seja através de novos arranjos institucionais, de novas regras para a regulação social e socioeconômica ou de novas modalidades de resolução de problemas sociais e socioeconômicos. Destaca-se, dessa maneira, conforme alguns estudos (LÉVESQUE, MENDELL, I999; LÉVESQUE, NINACS, 2000), que as inovações sociais estão presentes não apenas nos setores público e privado, mas também nas iniciativas da sociedade civil e da economia solidária, especialmente aquelas buscando responder demandas ou aspirações não satisfeitas ou mal satisfeitas pelo mercado ou pelo estado. (FRANÇA FILHO, 20I8) 
Essa extensão do perímetro de análise da inovação parece particularmente importante pois atualiza a pesquisa nesta área. É nessa perspectiva que se situa a contribuição valiosa de Andion (2016), após realizar significativa síntese dos estudos mais recentes sobre inovação social. Para esta autora, a inovação social emerge da iniciativa de indivíduos ou de grupos centrados no interesse público. (ANDION, 20I6; NOVY; LEUBOLT, 2005) Ao salientar a dimensão do interesse público, a definição proposta por Andion (2016) tenta escapar dos riscos de banalização que afeta a difusão do conceito de inovação social, ao passo em que também enfatiza seu papel enquanto motor de transformação social. (MURRAY; CAULIER-GRICE; MULGAN, 2OIO)

\section{Da banalização da inovação social à sua renovação}

Conforme sublinhamos anteriormente, o conceito de inovação social nasce da necessidade de estender a reflexão sobre inovação para além da sua dimensão tecnológica, especialmente em termos de produção industrial. Assim procedendo, esta corrente de pesquisa se interessou pelas práticas de inovação em uma grande variedade de domínios de atividades e campos de ação. Contudo, se a inovação se situa nas atividades mercantis e não mercantis, nas instituições públicas, no seio da sociedade civil e nos meios populares, sua definição se torna então polissêmica e perde um pouco sua densidade. É assim que atores dos negócios sociais podem se posicionar para propor um tratamento privado da inovação social com base na racionalidade do mercado. Para escapar dessa banalização, um esforço de ressignificação conceitual parece necessário. Para tanto, quatro critérios de análise podem ser apresentados no intuito de um melhor discernimento sobre a natureza da inovação que se quer compreender. Os quatro critérios são: a) a finalidade da inovação; b) o modo de acesso à inovação; c) o modo de uso ou de apropriação da inovação pelos utilizadores; e d) o modo de geração - proveniência/procedência - ou origem da inovação. (FRANÇA FILHO, 20I8)

O primeiro critério, a finalidade - nos ajuda a distinguir a inovação como resposta a uma necessidade social e a inovação como resposta a uma deman- 
da de mercado. No primeiro caso, a resposta não está condicionada a uma forma específica, enquanto que, no segundo, a inovação se traduz pela proposição de um bem ou de um serviço vindo de um operador privado. A confusão entre os dois é frequente, pois inúmeros bens e serviços estão disponíveis no mercado. A necessidade social acaba, assim, por se dissolver no uso de certos bens e serviços. Estes últimos são identificados pelos consumidores como necessidades e o ato de consumo acaba sendo reivindicado como uma necessidade social. Apenas o critério finalidade parece então insuficiente para evitar a banalização da inovação social.

O segundo critério diz respeito ao modo de acesso à inovação. Ele pode ocorrer através do mercado, o que supõe então uma relação de compra e um preço conformando um ato de consumo. A seletividade econômica caracteriza o acesso à inovação neste caso, pois trata-se de uma relação de compra. Mas, o acesso pode também ser assegurado por meio de serviço público. Nesse caso, os indivíduos devem preencher certos critérios de acesso definidos pela política pública concernida - critérios sociais, por exemplo - e entrar no formalismo exigido. Finalmente, o acesso pode também ocorrer através de serviços ofertados por organizações da sociedade civil e/ou, mais amplamente, organizações de economia solidária - em relação com instituições públicas governamentais ou independentemente destas. Nesse caso, o formalismo pode ser menor, pois as organizações conseguem mais facilmente se adaptar as necessidades dos atores ou se colocar como um facilitador da relação entre o indivíduo e a instituição pública. Ao final, a questão do modo de acesso se resume então a uma opção consumidor/clientes - em condições de recursos - e a uma opção cidadão/usuário - em condições de direito.

O terceiro critério concerne o modo de uso ou de apropriação da inovação pelo público-alvo. Esse critério avalia o grau de efetividade da inovação pela sua inscrição na vida cotidiana das pessoas. Uma questão comum neste âmbito diz respeito ao poder de replicação da inovação. Se esse poder é elevado, a apropriação seria então facilitada. Contudo, a replicabilidade supõe como retorno uma padronização e uma normalização da utilização, em nome do primado 
de uma lógica técnica. Esta, tende a descartar toda forma de adaptação social. A dimensão técnica da inovação inaugura um movimento de separação do social, que ela tenta domar para melhor o subordinar. A normalização se opera em detrimento dos contextos locais sociais e culturais. Em contraponto, a observação aprofundada das práticas revela a importância de se conceber soluções técnicas em consonância com o modo de vida dos sujeitos, de moradores, e inscritas nas suas relações sociais e culturais. A diversidade dos modos de utilização herdados dos diferentes contextos de uso se opõe a replicabilidade. Essa diversidade é uma garantia de criatividade social. Ela autoriza a emergência e o florescer de soluções próprias. Ela é uma manifestação da riqueza adormecida de cada cultura ou de cada território. É também uma perspectiva pertinente para se vislumbrar uma democratização do modo de uso da inovação, ou até uma "democracia dos usuários", conforme a expressão de Godbout (I987).

O quarto critério guarda relação com o modo de geração da inovação. Interrogar-se sobre as condições de emergência da inovação social supõe estudar o movimento de produção da inovação distinguindo-se as lógicas de difusão - descendente/top down e ascendente/botton up - e as lógicas de procedência ou proveniência - exógena e endógena. Nesse sentido, pode-se distinguir três casos de figura. No primeiro, as inovações sociais são concebidas por agentes externos - outsiders - ao território. Tais inovações seguem geralmente uma lógica descendente, segundo o preceito da transferência tecnológica. O pressuposto aqui é o de uma hierarquia de conhecimento separando os que conceberam a inovação e aqueles que são seus usuários. A natureza do conhecimento privilegiado neste caso é eminentemente técnico e não recobre os aspectos socioculturais. Há uma relação de poder que se estabelece entre os detentores de conhecimento e os outros. No segundo caso, as inovações sociais são concebidas pelos próprios utilizadores - lógica endógena. A dimensão técnica da inovação está imbricada ou enraizada na cultura da comunidade que a produz. O modo de geração da inovação segue a lógica de processos coletivos auto-organizados. Nesse sentido, a inovação social exprime a criatividade do coletivo e inventa formas nativamente compatíveis com as expectativas e os valores dos atores que o constitui. O espírito de paridade 
guia esses coletivos auto-organizados na forma de processo colaborativos ou de partilha por pares - peer to peer. Num terceiro caso de figura, combina-se uma lógica endógena com uma exógena. Trata-se, na maioria dos casos, de um tempo de alianças, de parcerias, ou de vínculos criados entre diferentes agentes institucionais. Pode ser o caso de uma relação entre uma universidade e uma comunidade, conforme vimos através do exemplo da incubação em economia solidária. A inovação é então definida como uma coconstrução entre os membros do coletivo e os representantes da universidade. Esse tipo de parceria enfatiza o diálogo e a escuta. Ela supõe uma abordagem fundada na empatia e na humildade da parte do ator externo.

Quadro 3 - A fronteira entre as inovações tecnológica e social

\begin{tabular}{|l|l|l|}
\hline $\begin{array}{l}\text { Natureza da inovação e } \\
\text { seus critérios }\end{array}$ & Inovação tecnológica & Inovação social \\
\hline Finalidade & Econômica & Social \\
\hline Modo de acesso & Serviços mercantis & $\begin{array}{l}\text { Serviços Públicos, Comuns e/ou } \\
\text { serviços mercantis re-significados }\end{array}$ \\
\hline Modo de apropriação & Técnica & Social \\
\hline Modo de geração & Exógena & Endógena e/ou Endógena-exógena \\
\hline
\end{tabular}

Fonte: adaptado de França Filho (2018).

Se o quadro acima tenta estabelecer uma fronteira conceitual mais clara entre as noções de inovação tecnológica e inovação social, seu intuito subjacente é sugerir uma compreensão mais rigorosa da inovação social como contraponto à sua banalização. Nesse sentido, o quadro procura delimitar em contornos mais nítidos o que seria e o que não seria inovação social. Quatro conclusões aparecem então possíveis, escapando risco de sua instrumentalização (FRANÇA FILHO, 20I8):

- a finalidade da inovação social não se confunde com um objetivo mercantil. Se a inovação mobiliza recursos econômicos, ela faz um trabalho de ressignificação da sua atividade econômica. Neste caso, os critérios econômicos mercantis são requalificados democraticamente, a partir de valores de cooperação e de reciprocidade; 
- a lógica de acesso à inovação social não se realiza através de mecanismos, critérios ou condições de mercado - exceto se a lógica de mercado é ressignificada através de mecanismos de regulação oriundos da própria sociedade, conforme testemunham as práticas de comércio justo ou de finanças solidárias. O acesso à inovação social acontece especialmente por meio do serviço público ou de serviços comuns ofertados pelos processos de auto-organização da sociedade;

- o modo de utilização ou apropriação da inovação social não passa por métodos de utilização normalizados. Ele pressupõe a consideração sobre os usos dos sujeitos, moradores e sua implicação. A inovação é socialmente apropriada e ela abre sobre a possibilidade de uma "democracia dos usuários";

- enfim, o modo de geração da inovação social não é concebido por sujeitos ou instituições fora do seu contexto de uso. A inovação social é gerada seja de uma forma endógena, seja numa relação entre endogenia e exogenia marcada pelos princípios da cooperação e da reciprocidade.

\section{Qual relação entre ciência, tecnologia e inovação?}

A reflexão trazida acima nos convida a repensar o paradigma da relação entre CT\&I que mais tem sido influente. Para tanto, partiremos de um olhar sobre cada um dos três termos dessa relação. A ciência primeiro é marcada pela oposição entre as ciências exatas e as ciências humanas e sociais (vs. ciências duras / ciências moles). Essa oposição traduz uma relação de força. As ciências exatas dominam as ciências humanas e sociais pela sua maior pretensão de cientificidade. Essa relação de força é tão importante que se exerce até mesmo no coração das ciências sociais. Assim, a economia ortodoxa se alimenta dessa pretensão. Ela se opõe à economia heterodoxa menos pela força de seus argumentos teóricos do que pelo uso de abordagens matematizáveis e matematizadas. Nesse sentido, ela responde a uma necessidade universal de certeza que é filosoficamente problemática, como mostra Dewey (20I4). Já a tecnologia, por sua vez, busca se apresentar na sua habitual neutralidade de procedimento. A tecnologia também se pretende fora das ciências sociais e humanas. Ora, as abordagens sociotécnicas mostraram clara- 
mente o forte vínculo entre tecnologia e ciências humanas e sociais. (EMERY; TRIST, I960, TRIST; BAMFORTH, I95I; WOODWARD, I970) De todo modo, a inovação permanece ainda marcada por uma visão tecnológica baseada nas ciências exatas. Essa forte ancoragem explica a dificuldade de pensar em uma inovação social não instrumentalizada. (FRANÇA FILHO, 2OI8)

No conjunto desses três termos, o paradigma da CT\&I angaria elevado reconhecimento nos meios político-institucionais. Sua visibilidade favorece essencialmente a inovação compatível com as soluções de mercado. Assim, quando um coletivo oriundo de um bairro popular se mobiliza em busca de soluções inovadoras para resolver problemas específicos em seu território, há uma grande chance de que a demanda seja considerada parte de uma política social. Responsáveis públicos geralmente não imaginam que essa demanda possa concernir um programa de investimentos em termos de CT\&I. Isso significa que é improvável que grandes investimentos em questões de inovação atinjam áreas socialmente inovadoras. Há, então, um paradoxo evidente: a inovação é invocada como uma resposta à crise, mas os recursos disponíveis para atendê-la não podem ir facilmente onde a crise é mais aguda.

De maneira mais geral, o descrédito que atinge as ciências humanas e sociais é bastante prejudicial. É amplamente aceito que o desenvolvimento da tecnologia seja alimentado por avanços no conhecimento das ciências naturais e da engenharia, no entanto, é menos consensual notar que grandes progressos nos serviços públicos e na ação pública possam se beneficiar do conhecimento nas ciências sociais. (LÉVESQUE, 2009) A pesquisa sobre inovação social é sem dúvida uma oportunidade de mudar as coisas. É preciso, para tanto, repensar o paradigma de CT\&I com a ajuda das ciências humanas e sociais, pois elas podem nos ajudar a melhor compreender as mudanças técnicas em andamento. Eles também podem promover uma abordagem abrangente para a formulação de políticas públicas e contribuir efetivamente através do trabalho das ciências sociais aplicadas. (LÉVESQUE, 2000, 200I) Essa renovação do pensamento sobre a inovação também nos convida a pensar um outro posicionamento para as ciências exatas e a engenharia. Existe um espaço possível e altamente relevante para o trabalho interdisciplinar que associa ciências exatas e ciências 
humanas e sociais no campo da inovação social. A produção de tais saberes é particularmente estimulante para imaginarmos novas articulações entre o conhecimento acadêmico e o popular. Trata-se, então, de um desafio de transformação sem precedentes. (FRANÇA FILHO, 2OI8)

\section{Características da inovação social na economia solidária}

As análises precedentes mostram a variedade e o alcance de outras práticas de organizações e gestão, a exemplo da economia solidária, em se constituir como um campo propício a valorização de uma inovação social não redutível à sua dimensão mercantil e técnica. Esse campo apresenta então alguns traços caraterísticos, conforme a abordagem aqui sugerida. (FRANÇA FILHO, 20I8)

O primeiro aspecto faz referência ao caráter coletivo das iniciativas. Nesse sentido, tais práticas não se confundem com qualquer forma de empreendedorismo privado pensado enquanto iniciativa individual. Embora ações individuais possam existir, elas pressupõem algum nível mais amplo de associação, isto é, alguma forma de suporte coletivo. Isso quer dizer que a inovação social busca qualificar a ação empreendedora com base no entendimento de que as soluções para problemas sociais podem ser mais sustentáveis num ambiente coletivo de ação.

O segundo aspecto característico é o fato de tais iniciativas coletivas pressuporem processos de aprendizagem de governança democrática. Nesse sentido, a inovação social induz processos de mudança ou construção de cultura política democrática, razão pela qual ela é concebida tanto numa lógica processual quanto na sua dimensão de aprendizagem. O caráter democrático da governança faz apelo aos princípios da autogestão ou do autogoverno na instituição de processos de organização sociopolítico e socioeconômico enquanto mecanismos de afirmação de valores como autonomia e liberdade de expressão. A ideia de governança democrática é pensada ainda para além do esforço de autogestão interna aos empreendimentos, mas envolve as diferentes formas e arranjos institucionais, conforme os diferentes tipos de redes ou arquiteturas institucionais que se desenham. 
O terceiro traço característico diz respeito ao enraizamento territorial. Isso significa que a inovação social não é jamais concebida independentemente das características - socioculturais, socioeconômicas ou sociopolíticas - do seu contexto local de inserção. Ela não se confunde com uma tecnologia cujo uso independe deste contexto. O propósito da economia solidária enquanto forma diferente de agir na economia é justamente de contribuir para uma reorganização das economias locais, através de estratégias de cooperação em rede na promoção do desenvolvimento que pressupõe novas formas de relações entre os sujeitos e também novas relações institucionais.

O quarto traço é a mobilização de saberes locais. Ou seja, a inovação social através da economia solidária se apoia no conhecimento e saberes disponíveis do próprio contexto em que emergem tais práticas. Essa é precisamente a razão pela qual ela - inovação social - tende a ser fortemente "temperada" culturalmente. Em grande parte dos casos, esse saber local interage com um saber científico ou técnico, do qual é portador o agente externo que se coloca nessa relação. Trata-se de uma interação na perspectiva transdisciplinar, isto é, de produção de um conhecimento síntese a partir do respeito e diálogo entre saberes distintos. Sob esse ponto de vista, rejeita-se a norma da transferência tecnológica e aposta-se nas possibilidades de coconstrução de soluções locais com base num padrão de respeito ético entre as partes envolvidas.

O quinto traço característico da inovação social através da economia solidária remete a uma dimensão psicossocial da prática: a produção de processos de reconhecimento dos sujeitos implicados. São, desse modo, induzidos processos de transformação pessoal na base das transformações institucionais que são evocadas. Essa dimensão do reconhecimento, intersubjetivamente compartilhada entre os sujeitos, é fruto da própria dinâmica de reconhecimento do local, sua cultura, seus saberes, bem como do modo de estabelecimento das relações pautado por princípios de autonomia e diálogo. Em contextos marcados por alto grau de vulnerabilidade socioeconômico, essa questão do reconhecimento adquire importância decisiva. Ela constitui a base de um tecido social fortalecido como condição para a criação da inovação. 